\title{
What Drives Credit Rating Changes? A Return Decomposition Approach $^{*}$
}

\author{
Hyungjin Cho ${ }^{* *}$ \\ Department of Business Administration, Universidad Carlos III de Madrid \\ Sunhwa Choi \\ Management School, Lancaster University
}

\begin{abstract}
This paper examines the relative importance of a shock to expected cash flows (i.e., cashflow news) and a shock to expected discount rates (i.e., discount-rate news) in credit rating changes. Specifically, we use a Vector Autoregressive (VAR) model to implement the return decomposition of Campbell and Shiller (1988) and Vuolteenaho (2002) to extract cash-flow news and discount-rate news from stock returns at the firm-level. We find that credit rating changes are, on average, more strongly associated with cash-flow news than with discountrate news, consistent with cash-flow news being more permanent than discount-rate news. We further find that both cash-flow news and discount-rate news are more strongly related to credit rating changes when they convey negative information about firm value. This asymmetric association is consistent with the non-linear nature of default risk and with the fact that rating agencies incorporate bad news sooner than good news into their rating revisions. This paper contributes to the literature by providing evidence on the relative importance of cash-flow news and discount-rate news in the credit rating process.
\end{abstract}

Keywords: Cash-flow news; Credit ratings; Discount-rate news; Return decomposition; Vector Autoregression (VAR) JEL Classification: G12, G24

\footnotetext{
* We appreciate helpful comments from Bok Baik, Lee-Seok Hwang, Moon Chul Kim, Jongchan Park, Steve Young, two anonymous referees, and seminar participants at the Lancaster University, Nanyang Technological University, Seoul National University, and Singapore Management University.

** Corresponding author, Departamento de Economia de la Empresa, Universidad Carlos III de Madrid, Calle Madrid 126, 28903 Getafe, Madrid, Spain, Phone: (34) 91624 9322, E-mail: cho.hyungjin@uc3m.es
} 


\section{Introduction}

Since the price of an asset is equal to the sum of expected cash flows discounted by appropriate discount rates, there are, by definition, only two sources that can change asset prices: a shock to expected cash flows (i.e., cash-flow news) and a shock to expected discount rates (i.e., discount-rate news). In terms of asset returns, the unexpected return can be decomposed into cash-flow news and discount-rate news (Campbell and Shiller, 1988). Using this return decomposition framework, a substantial body of research has examined the relative importance of cash-flow and discount-rate news in stock returns at the aggregate level (Campbell, 1991; Campbell and Ammer, 1993; Sadka, 2007; Chen et al., 2013) and at the firm-level (Vuolteenaho, 2002; Callen and Segal, 2004; Callen et al., 2005; Chen et al., 2013). An equally important but largely unexplored issue is the effect of cash-flow news and discount-rate news on the revision of default risk. Because default risk is based on the distribution of the expected cash flows relative to its outstanding debt (Merton, 1974; Cheng and Subramanyam, 2008), the probability of default should increase with a negative shock to the expected cash flows and a positive shock to the expected discount rate (i.e., an increase in the riskiness of expected cash flows). If so, what is the relative importance of these two components? Under what circumstances does the relative importance of these two types of news vary? To date, no empirical research has addressed these questions. We seek to answer these questions by examining the relation between the two components of news and credit rating changes.

An issuer-level corporate credit rating offers a good research opportunity to address the question of the relative importance of cash-flow news and discount-rate news in the probability of default. ${ }^{1}$ A corporate rating, also called "default risk rating" or "natural rating,"

\footnotetext{
1 At first glance, it seems natural to study corporate bond returns to examine the effects of cash-flow news and discount-rate news on the probability of default. However, it is hard to use the bond return in this research 
is a current opinion by rating agencies about an issuer's overall capacity to pay its financial obligations based on the assessment of the likelihood of default of the corporation (Standard \& Poor's (S\&P), 2006). This issuer-level rating is different from an issue-specific credit rating assigned to an individual debt issue because the former does not reflect any priority among obligations or issue-specific characteristics such as collateral and debt covenants. Additionally, the issuer-level rating evaluates the firm's fundamental creditworthiness with respect to a very long time horizon, instead of fixed debt maturities (S\&P, 2006). Using this issuer-level credit rating change as a proxy for the revision to the probability of default, we examine the relative importance of cash-flow news and discount-rate news.

A better understanding of the rating process is also important in itself. Despite the prominent role of credit ratings in the capital market, the rating process has been viewed more as a "black box" (Cifuentes, 2008). For example, we do not know much about what types of information are used and how different types of information are weighted in the rating process. ${ }^{2}$ By investigating the relative weight given to the two fundamental components of new information in the rating process, this study enhances our understanding of how rating agencies use various types of information.

To implement the return decomposition, we adopt the Vector Autoregressive (VAR) model of Vuolteenaho (2002), which uses return on equity (ROE) as the basic cash-flow fundamentals. We extract cash-flow news and discount-rate news at the firm-level from stock returns and then examine whether credit rating changes are more strongly associated with

setting because the bond return, by definition, has a minimal cash-flow-news component due to its fixed coupon and principal payments. As the growth rate of cash flows (coupons) is zero when the present value model of Campbell and Shiller (1988) is applied to bonds, prior studies decompose bond returns into a shock to future inflation, future real interest rate, and future excess bond return (Shiller and Beltratti, 1992; Campbell and Ammer, 1993; Abhyankar and Gonzalez, 2009). Moreover, the bond has various issue-specific characteristics such as covenants, collaterals, and priority, making it difficult to draw inferences with respect to firm-level cashflow news and discount-rate news.

2 At the hearings of the Securities and Exchange Commission (SEC), credit rating users stressed the importance of transparency in the rating process. Particularly, they argue that the market needs to understand the reasoning behind a rating decision and the types of information relied upon by the rating agencies (SEC, 2003, p. 33). 
cash-flow news or with discount-rate news. We further examine whether cash-flow news and discount-rate news become more relevant in updating the probability of default when the news conveys negative information about the firm.

This return decomposition approach offers several advantages in addressing our research questions for the following reasons. First, the model, derived from a dynamic accounting identity, provides a convenient and theoretically solid framework to disentangle cash-flow news and discount-rate news components. Second, the approach enables us to capture long-term and forward-looking information about the firm, as the news variables are measured from the stock returns, which reflect the most comprehensive information set. Specifically, cash-flow news is defined as the shock to the discounted sum of expected current and future earnings over the lifetime of the firm. Such extension of the horizon to the future periods is particularly relevant in rating decisions because credit rating agencies emphasize their long-term perspectives in rating decisions. For example, S\&P indicates that "S\&P's credit ratings are meant to be forward-looking, and their time horizon extends as far as is analytically foreseeable" (S\&P, 2006, p. 33). ${ }^{3}$ Finally, by using return decomposition approach, cash-flow news and discount-rate news can be measured in an internally consistent way (i.e., the sum of cash-flow news and discount-rate news equals the unexpected stock return), and thus a researcher can directly compare the effects of cash-flow news and discount-rate news on the variable of interest. ${ }^{4}$

The empirical findings are summarized as follows. We find that credit rating changes are, on average, more strongly associated with cash-flow news than with discount-rate news.

\footnotetext{
3 Similarly, Moody's corporate ratings are intended to be determined by each issuer's relative fundamental creditworthiness without reference to explicit time horizons (Cantor and Mann, 2003).

4 This approach is different from alternative methods in which cash-flow news is measured in one way and discount-rate news is measured the other way. For example, Botosan et al. (2011) capture cash-flow news from the analysts' revisions of earnings and target prices and calculate discount-rate news from two other sources: five-year Treasury bonds and changes in estimated market beta. Likewise, Chandra and Nayar (1998) use the analysts' forecast revisions and changes in market beta to measure cash-flow news and discount-rate news, respectively. 
In addition, the economic impact of cash-flow news on credit rating changes is greater than that of discount-rate news. For example, the interquartile change in cash-flow news from the lower quartile (Q1) to the upper quartile (Q3) increases the likelihood of being upgraded by $1.39 \%$, whereas the effect of interquartile change in discount-rate news is only $0.48 \%$. The findings are consistent with the notion that cash-flow news is more permanent than discountrate news (Campbell and Vuolteenaho, 2004; Campbell et al., 2010; Chen et al., 2013). This greater role of cash-flow news compared with discount-rate news is also consistent with the standard credit rating agencies' methodology in which fundamental analysis and cash flow adequacy are emphasized (S\&P, 2006). For example, S\&P (2006) indicates that "cash-flow analysis is the single most critical aspect of all credit rating decisions."

Further analyses show that the relation between credit rating changes and news variables becomes much stronger when the news conveys negative information about the firm compared with when it contains positive information. This asymmetric association is consistent with the non-linear nature of default risk in which downside risk is more relevant than the upside potential. This finding is also consistent with the fact that rating agencies incorporate bad news sooner than good news into their rating revisions (Beaver et al., 2006).

The main findings are robust to several additional tests, including alternative VAR estimations, a direct estimation of cash-flow news and discount-rate news using analysts' earnings forecasts from IBES, the use of lagged news variables, controlling for a potential shareholder-bondholder conflict, controlling for rating agencies' inefficient information process and their conflicts of interest, and the use of quarterly data.

This study contributes to the literature in several ways. First, it makes an important distinction between cash-flow news and discount-rate news by providing compelling evidence that cash-flow news is more relevant than discount-rate news in rating decisions. Thus, the paper extends a vast literature on the return decomposition to credit rating decisions. 
To our knowledge, this is the first study to formally examine the relative importance of cashflow news and discount-rate news in credit ratings. Additionally, we examine the non-linear relation between credit rating changes and news variables, whereas most studies in the literature do not distinguish between good and bad news.

Second, this study also contributes to the literature that investigates the determinants of credit ratings (Horrigan, 1966; Kaplan and Urwitz, 1979; Blume et al., 1998; Sengupta, 1998; Ahmed et al., 2002; Ashbaugh-Skaife et al., 2006; Jiang, 2008; Jorion et al., 2009; Lee, 2008; Ayers et al., 2010). Our paper complements this literature by focusing on the relative importance of various types of information used in the credit rating process.

Finally, this paper is closely related to several recent studies on the role of earnings in the debt market (Callen et al., 2009; Easton et al., 2009; DeFond and Zhang, 2011;

Gkougkousi, 2014). For example, Easton et al. (2009) examine the relation between earnings and bond returns and document that the relation is stronger when earnings convey bad news. We complement this line of research by using both cash-flow news and discount-rate news and by directly comparing the effects of these two components on credit rating changes. Furthermore, cash-flow news is appropriately measured in our study as the revision in the discounted sum of cash flows over the firm's lifetime. Hence, the way we define cash-flow news differs in an important respect from those in the previous studies on traditional proxies for cash-flow news, such as changes in historical earnings or cash flows.

This study, however, is subject to several caveats. First, the news variables measured from stock returns may contain measurement errors in the context of credit ratings due to a potential shareholder-bondholder conflict. Second, recent papers are raising concerns about the implementation of VAR model (Chen and Zhao, 2009; Chen et al., 2013). Third, there is growing concerns that credit ratings may not reflect the probability of default in an unbiased and timely manner due to rating agencies' own incentives or inefficient information process. 
We try to address all of these issues in Section 6.

The rest of the paper is organized as follows. In Section 2, we review the literature and develop our hypotheses. We provide the research design in Section 3 and describe the sample and descriptive statistics in Section 4. Then we report the results of empirical tests and additional tests in Sections 5 and 6. Section 7 concludes the study.

\section{Literature Reviews and Hypothesis Development}

\subsection{Literature Reviews}

A credit rating provides the assessment of an obligor's overall capacity and willingness to meet its financial obligations (S\&P, 2006). The primary role of the credit rating in the capital market is to reduce information asymmetry by providing information on rated firms or securities based on their credit risk assessment (Boot et al., 2006). Consistent with this role, there is a large body of literature on the information content of credit rating changes. One stream examines the stock or bond market reactions to the announcement of a rating change (Holthausen and Leftwich, 1986; Hand et al., 1992; Goh and Ederington, 1993; Kliger and Sarig, 2000; Dichev and Piotroski, 2001; Jorion et al., 2005; Beaver et al., 2006). They find that both bond and stock prices respond to credit rating changes, particularly when ratings are downgraded. Another stream examines the revisions in analysts' earnings forecasts upon rating changes (Chandra and Nayar, 1998; Ederington and Goh, 1998). Their results suggest that analysts revise their earnings forecasts downward (upward) following rating downgrades (upgrades).

While these studies provide valuable insights into the information content of rating changes, the types of information used by rating agencies and their relative importance are still largely unknown. A return decomposition approach of distinguishing between cash-flow news and discount-rate news by Campbell and Shiller (1988) provides a novel framework for 
investigating the types of new information used in rating decisions. Campbell and Shiller (1988) develop a dividend-ratio model that relates the dividend-price ratio to the expected discount rates and growth rates of dividends. Since then, the return decomposition method has led to a voluminous literature across many disciplines, including finance, macroeconomics, and accounting. While this approach has been used largely in the stock market, the framework can be also applied to the general settings because the key concept is based on the fundamental notion of asset valuation. For example, because default risk is based on the distribution of the firm's expected cash flows (Merton, 1974; Cheng and Subramanyam, 2008), the probability of default increases with a negative shock to the expected cash flows and an increase in the riskiness of expected cash flows. As corporate credit ratings assess the probability of default, the rating downgrades (upgrades) should occur when rating agencies revise downward (upward) their expectations of future cash flows (e.g., deterioration in the firm's future performance) and/or when they revise upward (downward) their evaluation of the riskiness of that cash flow stream (e.g., an increased volatility).

Only a few papers on credit ratings adopt this framework of distinguishing between cash-flow news and discount-rate news. For example, Cheng and Subramanyam (2008) suggest that analyst following can affect credit ratings by influencing both the mean and conditional variance of expected cash flows due to analysts' monitoring and informational roles. Their argument is consistent with the return decomposition framework that credit rating changes are affected by both cash-flow news and discount-rate news. Goh and Ederington (1993) investigate the rating changes provided by Moody's. They find that downgrades due to expected deterioration in financial prospects, which are presumably related to cash-flow news, are most common and are associated with significant stock market reactions. Likewise, Chandra and Nayar (1998) examine analysts' earnings forecast revisions to determine whether commercial paper rating downgrades convey information about changes in expected 
cash flows. They also examine the change in systematic risk following downgrades to see whether rating downgrades affect the perceived riskiness of the firm. They find that commercial paper downgrades are associated with a downward revision in analysts' earnings forecasts and are also followed by an increase in the market beta, suggesting that credit rating changes have implications for both firm's expected cash flows and expected returns. However, they do not provide evidence on the relative importance of these two components in rating decisions.

There is a substantial body of literature on the relative importance of cash-flow news and discount-rate news in the stock market. Campbell (1991) and Campbell and Ammer (1993) use a VAR model based on the dividend-ratio model of Campbell and Shiller (1988) to decompose the aggregate stock returns into cash-flow news and discount-rate news. They find that the variance of market-level discount-rate news dominates the variance of marketlevel cash-flow news, suggesting that the aggregate stock returns are mainly driven by news about the expected discount rate. Vuolteenaho (2002) extends this variance decomposition framework to the firm-level using ROE instead of dividend growth as the basic cash-flow fundamentals. He shows that the firm-level stock returns are mainly driven by cash-flow (earnings) news. He reconciles his results with previous studies analyzing the aggregate level returns by showing that cash-flow information is largely firm-specific, while discount-rate information is driven by systematic and macroeconomic components. Hence, if firm-level cash-flow news can be largely diversified away in aggregate portfolios, cash-flow news will be less influential at the aggregate level returns than discount-rate news. In contrast, Chen et al. (2013) suggest that cash-flow news is more important than discount-rate news even at the aggregate level because the diversification effect does not change the relative importance of the news variables.

\subsection{Hypotheses Development}


It is not clear ex ante whether cash-flow news or discount-rate news drives the credit rating change. On the one hand, cash-flow news is expected to be more relevant in rating decisions than discount-rate news. For example, Campbell and Vuolteenaho (2004) and Campbell et al. (2010) suggest that cash-flow news has a permanent impact on stock prices, while discount-rate news has only a temporary impact. This is because poor returns driven by an increase in discount rates are partially offset by improved prospects for future investment opportunities. In contrast, changes in firm value due to the revision in expected cash flows are never subsequently reversed. Based on this argument, Campbell and Vuolteenaho (2004) break down firm betas into cash-flow betas and discount-rate betas and find that value stocks and small stocks have higher cash-flow betas than do growth stocks and large stocks. Moreover, discount-rate news may be less relevant in the revisions in the credit rating because a relative (i.e., ordinal) ranking of credit risk may not be affected by macroeconomic factors.

On the other, cash-flow news may have limited implications for rating changes because bondholders' cash flows (i.e., interest and principal payments) are fixed. Therefore, a shock to cash flows may not be an important news as long as expected cash flows can cover the interest and principal payments. In summary, it is an empirical question whether rating changes are more strongly associated with cash-flow news or with discount-rate news.

We next examine whether the association between credit rating changes and news variables becomes stronger when the news conveys negative information about firm value. For example, news indicating deteriorating cash flows has a direct impact on the revision in default risk, whereas improved expected cash flows may have a limited impact on the revision of default risk. Hence, we expect that both cash-flow news and discount-rate news are more strongly related to credit rating changes when the information conveys bad news than when it contains good news (Beaver et al., 2006; Callen et al., 2009; Easton et al., 2009). 


\section{Research Design}

\subsection{The Return Decomposition ${ }^{5}$}

Unexpected stock return $\left(r_{t}-\mathrm{E}_{\mathrm{t}-1}\left(r_{t}\right)\right)$ can be expressed by the sum of cash-flow news $(N c f)$ and (the negative of) discount-rate news $(\mathrm{Nr})$ as follows:

$$
r_{t}-\mathrm{E}_{\mathrm{t}-1}\left(r_{t}\right)=N c f_{t}-N r_{t}
$$

where $r_{t}$ denotes the log cum dividend stock return at time $t$ and $\mathrm{E}_{\mathrm{t}-1}\left(r_{t}\right)$ denotes the market's expectation at time $t-1$ of the stock return of time $t . N c f_{t}$ is cash-flow news at time $t$ defined as the market's revision from period $t-1$ to $t$ of expected earnings over the lifetime of the firm. Intuitively, cash-flow news is the stock returns that would have been realized if expected returns had not changed (Cohen et al., 2002). $N r_{t}$ is discount-rate news at time $t$ defined as the market's revision from period $t$ - 1 to $t$ of expected discount rates. A positive shock to expected cash flows (expected discount rate) results in a positive (negative) stock return.

Formally, cash-flow news and discount-rate news in Vuolteenaho (2002) are defined as follows:

$$
\begin{aligned}
& N c f_{t}=\Delta \mathrm{E}_{t} \sum_{j=0}^{\infty} \rho^{j} \text { roe }_{t+j} \\
& N r_{t}=\Delta \mathrm{E}_{t} \sum_{j=1}^{\infty} \rho^{j} r_{t+j}
\end{aligned}
$$

where $\Delta \mathrm{E}_{\mathrm{t}}=\mathrm{E}_{\mathrm{t}}-\mathrm{E}_{\mathrm{t}-1}$ denotes the change in expectation from period $t$ - 1 to period $t, \rho$ is a constant discount coefficient, and roe ${ }_{t}$ is the log return on book value equity at time $t$.

We implement the return decomposition using a VAR model with three state variables: stock returns, earnings deflated by the beginning book value of equity, and the book-to-market ratio (Vuolteenaho, 2002). ${ }^{6}$ All variables are cross-sectionally demeaned.

\footnotetext{
5 Callen and Segal (2010) provide an excellent summary of the variance decomposition method.

${ }^{6}$ State variables include the book-to-market ratio, because Vuolteenaho (2002) derived the decomposition 11
} 


$$
\begin{aligned}
& r_{t}=\alpha_{1} r_{t-1}+\alpha_{2} \text { roe }_{t-1}+\alpha_{3} b m_{t-1}+\eta_{1 \mathrm{t}} \\
& \text { roe }_{t}=\beta_{1} r_{t-1}+\beta_{2} \text { roe }_{t-1}+\beta_{3} b m_{t-1}+\eta_{2 \mathrm{t}} \\
& b m_{t}=\gamma_{1} r_{t-1}+\gamma_{2} \text { roe }_{t-1}+\gamma_{3} b m_{t-1}+\eta_{3 \mathrm{t}}
\end{aligned}
$$

where (Compustat names are presented in parentheses. The firm subscript $i$ is

omitted.)

$$
\begin{aligned}
& r_{t}= \text { The log of one plus the annual cum dividend return minus the log } \\
& \text { of one plus the annualized three-month Treasury bill rate. The 12- } \\
& \text { month return cumulation period starts three months after the } \\
& \text { beginning of the current fiscal year. Stock return data is retrieved } \\
& \text { from CRSP }{ }^{7} \text {; } \\
& \text { The log of one plus ROE minus the log of one plus the annualized } \\
& \text { three-month Treasury bill rate. ROE is computed as income before } \\
& \text { extraordinary items (IB), divided by the beginning of period book } \\
& \text { value of equity (CEQ); and } \\
& \text { The log of the book-to-market ratio at year-end. The book-to- } \\
& \text { market ratio is the book value of equity (CEQ) divided by the } \\
& \text { market value of equity (CSHO*PRCC_F). }
\end{aligned}
$$

The above equations $(4 a)-(4 c)$ can be expressed in matrix notation as follows:

$$
\mathrm{z}_{\mathrm{t}}=\Gamma \mathrm{z}_{\mathrm{t}-1}+\eta_{\mathrm{t}}
$$

where

$$
\mathrm{z}_{\mathrm{t}}=\left(\begin{array}{c}
r_{t} \\
\operatorname{roe}_{t} \\
b m_{t}
\end{array}\right), \Gamma=\left(\begin{array}{lll}
\alpha_{1} & \alpha_{2} & \alpha_{3} \\
\beta_{1} & \beta_{2} & \beta_{3} \\
\gamma_{1} & \gamma_{2} & \gamma_{3}
\end{array}\right), \eta_{\mathrm{t}}=\left(\begin{array}{l}
\eta_{1 t} \\
\eta_{2 t} \\
\eta_{3 t}
\end{array}\right)
$$

As shown by Campbell and Shiller (1988), cash-flow news $\left(N c f_{t}\right)$ and discount-rate news $\left(N r_{t}\right)$ can be conveniently computed as follows: ${ }^{8}$

$$
\begin{aligned}
& N c f_{t}=\left(\mathrm{e}_{1}+\lambda_{1}\right)^{\prime} \eta_{\mathrm{t}} \\
& N r_{t}=\lambda_{1}{ }^{\prime} \eta_{\mathrm{t}}
\end{aligned}
$$

where ' denotes the transpose operator, $\mathrm{e}_{\mathrm{k}}{ }^{\prime}=(0, \ldots, 1, \ldots, 0)$ is a row vector with one

model based on the definition of the market-to-book ratio.

7 When the firm is delisted, we follow Beaver et al. (2007).

8 As in Vuolteenaho (2002), discount-rate news is computed directly, and cash-flow news is computed residually by subtracting discount-rate news from unexpected returns. In Section 6, we explore the other options of computing cash-flow news directly (Chen and Zhao, 2009). 
as the $k$ th element, and zero elsewhere, and $\lambda_{\mathrm{k}}{ }^{{ }^{\prime}}=\mathrm{e}_{\mathrm{k}}{ }^{\prime} \rho \Gamma(\mathrm{I}-\rho \Gamma)^{-1}$ with $(\mathrm{I}-\rho \Gamma)^{-1}$ being the matrix equivalent of the present value of the sum.

The VAR coefficient matrix $(\Gamma)$ is assumed to be constant over time and across firms. ${ }^{9}$ We use the ordinary least squares (OLS) to estimate the VAR coefficients. $\rho$ is assumed to take a value of 0.967 as in Vuolteenaho (2002). ${ }^{10}$

As cash-flow news $\left(N c f_{t}\right)$ is the sum of the shock to the current earnings and the shock to the future earnings, it can be further decomposed into current-period cash-flow news $\left(C N c f_{t}\right)$ and future-period cash-flow news $\left(F N c f_{t}\right)$. The current-period cash-flow news is measured as the residual from Equation (4b), $\eta_{2 t}$, and the future-period cash-flow news is measured as the difference between total cash-flow news and current-period cash-flow news as follow (Callen et al., 2010):

$$
N c f_{t}=C N c f_{t}+F N c f_{t}
$$

\subsection{The Rating Change Model}

To examine the relative importance of cash-flow news and discount-rate news in rating decisions, we compare the magnitude of the coefficients on $N c f_{t}$ and $N r_{t}$ and their marginal effects in the following model:

$$
\begin{aligned}
& \Delta R A T I N G_{t}=\beta_{0}+\beta_{1} N c f_{t}+\beta_{2} N r_{t}+\beta_{3} \Delta S I Z E_{t}+\beta_{4} \Delta I N T C O V_{t}+\beta_{5} \Delta R O A_{t} \\
& +\beta_{6} L E V_{t}+\beta_{7} \Delta C A P \text { INTEN } N_{t}+\beta_{8} \Delta A G R W_{t}+\beta_{9} \Delta S T D R E T_{t} \\
& + \text { industry- and year-fixed effects }+\varepsilon_{t}
\end{aligned}
$$

where

$$
\begin{aligned}
\triangle R A T I N G_{t}= & \begin{array}{l}
R A T I N G_{t}-R A T I N G_{t-1}, \text { where } R A T I N G_{t} \text { is S\&P's long-term issuer-level } \\
\text { credit ratings (SPLTICRM) as of three months after the fiscal year end, } \\
\text { converted to numerical values between } 1 \text { (CCC }+ \text { or below) and } 17
\end{array} \\
& \text { (AAA) according to Panel B of Table 1; } \\
N c f_{t}= & \text { Cash-flow news as computed in Equation (6); } \\
N r_{t}= & \text { Discount-rate news as computed in Equation (7); } \\
\Delta S I Z E_{t}= & S I Z E_{t}-\text { SIZE }_{t-1}, \text { where } \text { SIZE }_{t} \text { is the log of market value of equity (CSHO }
\end{aligned}
$$

\footnotetext{
9 In Section 6, we relax this restriction by estimating $\Gamma$ for each industry or for each subperiod sample.

${ }^{10}$ The results are not affected by the value of $\rho$ within the range between 0.95 and 1 . 


$$
\begin{aligned}
& \text { * PRCC_F); }
\end{aligned}
$$

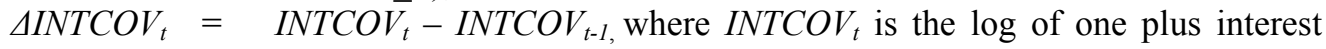

$$
\begin{aligned}
& \Delta R O A_{t}=R O A_{t}-R O A_{t-1} \text {, where } R O A_{t} \text { is income before extraordinary items (IB) } \\
& \text { divided by average total assets (AT); } \\
& \Delta L E V_{t}=L E V_{t}-L E V_{t-1} \text {, where } L E V_{t} \text { is the ratio of total debt (DLTT+DLC) to total } \\
& \text { assets (AT); } \\
& \triangle C A P_{-} I N T E N_{t}=C A P_{-} I N T E N_{t}-C A P_{-} I N T E N_{t-1} \text {, where CAP_INTEN } N_{t} \text { is gross property, } \\
& \text { plant and equipment (PPEGT) divided by total assets; } \\
& \triangle A G R W_{t}=A G R W_{t}-A G R W_{t-1} \text {, where } A G R W_{t} \text { is the total asset growth defined as } \\
& \text { (Total assets }- \text { Total }_{\mathrm{t}} \text { assets }_{\mathrm{t}-1} \text { )/Total } \text { assets }_{\mathrm{t}-1} \text {; and } \\
& \triangle S T D R E T_{t}=\text { STDRET }_{t}-\text { STDRET }_{t-1} \text {, where STDRET } T_{t} \text { is the standard deviation of } \\
& \text { daily stock returns during the fiscal year. }
\end{aligned}
$$

The dependent variable $\left(\triangle R A T I N G_{t}\right)$ is the change in firm's credit ratings between year $t$ and $t-1 .{ }^{11}$ Credit ratings measured as of three months after the fiscal year-end $\left(\right.$ RATING $\left._{t}\right)$ are converted to numerical values between $1(\mathrm{CCC}+$ or below) and 17 (AAA) according to Panel $\mathrm{B}$ of Table 1 . Then $\triangle R A T I N G_{t}$ is defined as the first difference of RATING . $_{\text {. }}$ A positive value of $\triangle R A T I N G_{t}$ indicates a rating upgrade, a negative value indicates a rating downgrade, and a zero value indicates no rating change. Because a credit rating is an ordered categorical variable and thus a rating change does not represent an equally-spaced discrete interval, we use the ordered logit specification.

A set of control variables that have been documented to be associated with credit rating changes are also included in the model (Jiang, 2008; Lee, 2008; Ayers et al., 2010). We include the change in firm size $\left(\triangle S I Z E_{t}\right)$, interest coverage ratios $\left(\triangle I N T C O V_{t}\right)$, return on assets $\left(\triangle R O A_{t}\right)$, financial leverage $\left(\triangle L E V_{t}\right)$, capital intensity $\left(\triangle C A P_{-} I N T E N_{t}\right)$, asset growth $\left(\triangle A G R W_{t}\right)$, and the standard deviation of stock returns $\left(\triangle S T D R E T_{t}\right)$. Finally, we include industry and year indicators to control for any effect by industry membership and

11 The determinant model of the level of credit ratings may suffer from potential correlated omitted variable problems. In addition, credit ratings are "sticky," which implies that any correlated omitted variables or the error terms from a ratings-level regression are likely correlated over time. We use the "change specification" in which both dependent and independent variables are all measured as the change to mitigate the effects of correlated omitted variables and autocorrelation in the error terms (Jiang, 2008; Ayers et al., 2010). Furthermore, the use of changes in ratings is consistent with our research question that examines how new information captured in cashflow news and discount-rate news affects the rating changes. 
macroeconomic events. For easier economic interpretation, we standardize all independent variables by subtracting the sample mean from them and then dividing the difference by the standard deviation. With this, we can directly compare the coefficients on cash-flow news $(\mathrm{Ncf})$ and discount-rate news $(\mathrm{Nr})$ because they both represent one standard deviation change in each variable (Ashbaugh-Skaife et al., 2006; Hirshleifer et al., 2009; Chava and Purnanandam, 2010). We report $p$-values based on robust standard errors clustered by firm (Peterson, 2009).

Significant coefficients on $\beta_{1}$ and $\beta_{2}$ in Equation (9) indicate that rating agencies respond to cash-flow news and discount-rate news. The coefficient on cash-flow news $\left(\beta_{1}\right)$ is expected to be positive, while the negative sign is expected for discount-rate news $\left(\beta_{2}\right)$.

\section{Sample and Descriptive Statistics}

Panel A of Table 1 summarizes the sample selection procedure. The initial sample is from firm-year observations with available variables to estimate the VAR model on Compustat during the period of 1986-2008. We exclude firms in the utilities (SIC 4900-4999) and financial services (SIC 6000-6999) industries. ${ }^{12}$ We require firms to have a December fiscal year-end to align accounting variables across firms. We require non-missing values for current and lagged stock returns, book-to-market ratios, and return on equity. We eliminate observations with lagged market value less than $\$ 10$ million. The VAR state variables are winsorized at a $1 \%$ and $99 \%$ level each year to mitigate outliers. The sample used to estimate the VAR model is 45,486 firm-year observations. Then, we require S\&P's issuer-level credit ratings to calculate the rating changes. After excluding missing data to obtain other control variables, the final sample is 11,354 firm-year observations representing 1,541 distinct firms.

12 The sample period starts in 1986, because credit rating data on Compustat are available from 1985 and the observations in 1985 are dropped to obtain the first difference in variables. 
Panel B of Table 1 shows the distribution of credit ratings $\left(R A T I N G_{t}\right) . R A T I N G_{t}$ takes the value between 1 and 17, with a higher value indicating better credit quality. We combine all ratings below $\mathrm{CCC}+$ into one category of $\mathrm{CCC}+$ because of the limited number of observations under CCC + (Jiang, 2008). Firms with investment-grade ratings (BBB- or above) are $60.2 \%$ of the sample, and firms with non-investment-grade ratings (BB+ or below) make up the remaining $39.8 \%$. Panel $\mathrm{C}$ presents the distribution of credit rating changes, which are the dependent variable for our analyses. ${ }^{13}$ The distribution shows that the majority of firmyears do not experience rating changes (76.55\%), while downgrades $(13.34 \%)$ are more common than upgrades $(10.11 \%)$. This distribution of credit rating changes is similar to that in prior studies (Jiang, 2008; Ayers et al., 2010).

Panel A of Table 2 provides the descriptive statistics for variables in the regressions. We report the descriptive statistics for the raw numbers before the standardization. The median firm-year has a $R A T I N G_{t}$ of 9, corresponding to the S\&P letter grade of BBB. $\triangle R A T I N G_{t}$ has a mean value of -0.07 with a standard deviation of 0.75 . The average values of cash-flow news $\left(N c f_{t}\right)$ and discount-rate news $\left(N r_{t}\right)$ are $6.0 \%$ and $-0.4 \%$, respectively. $N c f_{t}$ has a larger standard deviation $(0.35)$ than $N r_{t}(0.11)$. Panel B of Table 2 reports the descriptive statistics separately for the firms with rating downgrades and those with rating upgrades. The sample with rating upgrades (downgrades) has positive (negative) values of cash-flow news and negative (positive) values of discount-rate news, consistent with the expectation.

Table 3 reports the Pearson correlation coefficients among variables. $\triangle R A T I N G_{t}$ is positively associated with $N c f_{t}, C N c f_{t}, F N c f_{t}, \triangle S I Z E_{t}, \triangle I N T C O V_{t}, \triangle R O A_{t}$, and $\triangle A G R W_{t}$, while it is negatively associated with $N r_{t}, \triangle L E V_{t}, \triangle C A P_{-} I N T E N_{t}$, and $\triangle \operatorname{STDRET}_{t} . \triangle R A T I N G_{t}$ is more strongly associated with $N c f_{t}(\rho=0.23)$ than with $N r_{t}(\rho=-0.04)$. There is a negative

\footnotetext{
13 We exclude firm-year observations with $\left|\triangle R A T I N G_{t}\right|>4$. This dramatic change in ratings in adjacent years may be due to coding errors or significant events such as mergers or acquisitions (Jiang, 2008). 
correlation $(\rho=-0.18)$ between $N c f_{t}$ and $N r_{t}$ (Callen et al., 2010).

\section{Empirical Results}

\subsection{The VAR Estimation}

Table 4 reports the estimated VAR coefficient matrix $(\Gamma)$ and variance-covariance matrix $(\Sigma)$ from the pooled OLS. Note that the sample used for the VAR estimation is 45,486 observations, before requiring the S\&P credit ratings and other control variables (See Panel A in Table 1). We report the OLS estimate of the parameter with robust standard errors obtained using the Rogers' (1993) method in parentheses and the jackknife method outlined by Shao and Rao (1993) in brackets. ${ }^{14}$ The current returns $\left(r_{t}\right)$ are high when past returns $\left(r_{t-1}\right)$, return on equity (roe $\left.t_{t-1}\right)$, and book-to-market ratios $\left(b_{t-1}\right)$ are high. Current profitability $\left(\right.$ roe $\left._{t}\right)$ is positively related to past returns, profitability, and book-to-market ratios. Finally, current book-to-market ratios $\left(b m_{t}\right)$ are negatively related to past stock returns, but are positively related to past profitability and past book-to-market ratios. Table 4 also presents the coefficients of the linear function $\lambda_{1}$ 'and $\left(\mathrm{e}_{1}+\lambda_{1}\right)^{\prime}$ that map the VAR innovations $\left(\eta_{\mathrm{t}}\right)$ to discount-rate news and cash-flow news, respectively. $\lambda_{1}{ }^{\prime}$, defined as $\mathrm{e}_{1}{ }^{\prime} \rho \Gamma(\mathrm{I}-\rho \Gamma)^{-1}$, captures the significance of each individual VAR shock to discount-rate expectations. $\lambda_{1}{ }^{\prime}$ shows that stock returns, profitability, and book-to-market ratios are all positively related to discountrate news, consistent with the finding in Campbell et al., (2010).

\subsection{The Relative Importance of Cash-flow News and Discount-rate News}

\subsubsection{Comparing the magnitude of the coefficients}

Column (1) of Table 5 reports the ordered logit results when both $N c f_{t}$ and $N r_{t}$ are included along with several control variables. The coefficient on $N c f_{t}$ is significantly positive,

14 The Shao-Rao's (1993) jackknife method estimates the parameter after dropping one cross-section at a time and results in a time series of estimates. This jackknife method yields consistent standard errors even in the presence of cross-sectional correlation (See Appendix B in Vuolteenaho (2002)). 
and the coefficient on $\mathrm{Nr}_{t}$ is significantly negative, consistent with the prediction. In terms of their magnitudes, the coefficient on $N c f_{t}(0.244)$ is about two times greater in absolute value than the coefficient on $N r_{t}(-0.123)$. Note that we can directly compare these two coefficients on $N c f_{t}$ and $N r_{t}$ because all independent variables are standardized to have zero means and unit variances. The statistical test confirms that these two coefficients are statistically different $(p$-value $=0.01)$. This finding supports that cash-flow news is more important in driving credit rating changes than is discount-rate news. ${ }^{15}$

The coefficients on the other control variables are generally consistent with prior research (Jiang, 2008; Ayers et al., 2010). The increases in firm size $\left(\triangle S I Z E_{t}\right)$, interest coverage $\left(\triangle I N T C O V_{t}\right)$, return on assets $\left(\triangle R O A_{t}\right)$, and capital intensity $\left(\triangle C A P_{-} I N T E N_{t}\right)$ are positively associated with the likelihood of rating upgrades. On the other hand, the increases in financial leverage $\left(\triangle L E V_{t}\right)$, asset growth $\left(\triangle A G R W_{t}\right)$, and stock return volatility $\left(\triangle \mathrm{STDRET}_{\mathrm{t}}\right)$ are associated with the higher likelihood of rating downgrades. Note that $\triangle R O A_{t}$ is only marginally significant when $N c f_{t}$ is included in the model.

In Column (2), we decompose $N c f_{t}$ into $C N c f_{t}$ and $F N c f_{t}$. The two components of total cash-flow news are both significantly positive, and the magnitudes of the two coefficients are not statistically different $(p$-value $=0.24)$. This suggests that shocks to current and future cash flows are equally important in rating revisions.

We also estimate the ordered logit after excluding firm-year observations with zero rating changes. Since $76.55 \%$ of the sample firms experience no credit rating change (see Panel C of Table 1), there may be concerns that those with zero values in the dependent

\footnotetext{
${ }^{15}$ As an alternative way to compare the relative importance of cash-flow news and discount-rate news, we estimate the ordered logit models of credit rating changes using either cash-flow news or discount-rate news as a sole independent variable and then compare the pseudo $\mathrm{R}^{2}$ of the model across the models. In untabulated results, we find that McFadden's (1973) pseudo $\mathrm{R}^{2}$ and McKelvey and Zavoina's (1975) pseudo $\mathrm{R}^{2}$ are higher when we use the cash-flow news as the independent variable compared with those when we use the discountrate news as the independent variable. This is also consistent with our argument that cash-flow news better explains the credit rating changes than does discount-rate news. 
variable can unduly affect the results. To address this issue, we exclude observations with zero rating changes from the sample and re-estimate the model with the smaller sample $(\mathrm{N}=$ 2,662). In Column (3), the results are similar to those reported in Column (1). Finally, we estimate the OLS instead of the ordered logit and report the result in Column (4). The results are not affected by this change, which confirms that the findings are not sensitive to the choice of estimation method.

\subsubsection{Comparing the economic impacts}

While the findings in Table 5 support the notion that rating agencies revise their assessment of the credit quality of a firm upon cash-flow news to a greater extent than upon discount-rate news, it is not straightforward to quantify the economic impacts of changes of explanatory variables on rating changes because the logit regression is a nonlinear model. To more readily assess the economic significance of the results, we use an alternative classification scheme in which the dependent variable is either a rating upgrade or downgrade. Specifically, we define $U P G R A D E_{t}\left(D O W N G R A D E_{t}\right)$ as one if credit ratings are upgraded (downgraded), and zero otherwise and then estimate the binary (instead of ordered) logit. To assess the economic significance, we use two approaches (Ashbaugh-Skaife et al., 2006). First, we present the marginal effect of each variable, which is evaluated at the mean value of each variable, holding all other variables at their means. The marginal effect represents the change in the probability of being upgraded (or downgraded) upon infinitesimal change of the independent variable. Second, we calculate the change in the probability of being upgraded (or downgraded) as the value of the explanatory variable is moved from its lower quartile (1Q) to its upper quartile (3Q), while holding other variables constant at their means.

The binary logit results presented in Columns (1) and (4) of Table 6 are similar to those reported in Table 5. A shock to future cash flows is positively (negatively) associated with the likelihood of being upgraded (downgraded), while a shock to expected return is 
positively associated with the likelihood of being downgraded. The notable difference between the ordered and binary logit results is that the coefficient on $N r_{t}$ is not significant in Column (1) of Table 6 in which the probability of being upgraded is estimated. With respect to the economic impact, the marginal effect of $N c f_{t}$ is greater in absolute value than that of $N r_{t}$ for both upgrades $(0.013$ versus -0.005$)$ and downgrades (-0.024 versus 0.014$)$ as presented in Columns (2) and (5). The change in the probability of rating changes as a result of moving the variable from Q1 to Q3 is also greater for $N c f_{t}$ than for $N r_{t}$, as presented in Columns (3) and (6). For example, an interquartile change of $N c f_{t}$ is associated with a $1.39 \%$ increase in the probability of being upgraded while the effect of $N r_{t}$ is only $0.48 \%$. Similarly, an interquartile change of $N c f_{t}\left(N r_{t}\right)$ is associated with a $2.51 \%$ decrease $(1.46 \%$ increase) in the probability of being downgraded. Given that the probability of being upgraded (downgraded) evaluated at the means of all variables is $7.96 \%(10.23 \%)$, this change in the likelihood of rating changes appears to be economically significant.

\subsection{Asymmetric Response of Rating Changes with respect to Bad News}

To test whether the association between credit rating changes and news variables becomes stronger when the news conveys negative information about firm value, we divide the sample into two groups by the sign of news variables. In Columns (1) and (2) of Table 7, the sample is partitioned by the sign of cash-flow news. The coefficient on $N c f_{t}$ is not significant in Column (1) for those with positive cash-flow news, while it is significant and positive in Column (2) for those with negative cash-flow news. Note that this positive coefficient on $N c f_{t}$ in Column (2) indicates that more negative values of $N c f_{t}$ are associated with more rating downgrades (i.e., lower values of $\triangle R A T I N G$ ). However, the coefficients on $N r_{t}$ are not affected by the sign of cash-flow news (i.e., they are negative and significant for both subsamples). Regarding the relative importance, cash-flow news seems to be less relevant in updating ratings when it carries positive information, whereas cash-flow news 
dominates discount-rate news when there is bad news about expected cash flows.

In Columns (3) and (4), when the sample is divided by the sign of discount-rate news, an asymmetric pattern emerges for discount-rate news, which mirrors the previous finding for cash-flow news. The coefficient on $N r_{t}$ is not significant for the subsample that has experienced a decrease in risk (Column (3)), whereas it is significantly negative for the subsample that has experienced an increase in risk (Column (4)). Here, the negative coefficient $N r_{t}$ indicates that news of discount rate increases is associated with rating downgrades. However, the coefficients on $N c f_{t}$ are significant for both groups regardless of the sign of discount-rate news. In addition, the coefficient on $N c f_{t}$ is greater in absolute value than that on $N r_{t}$ for both groups.

Overall, the relation between rating changes and news variables becomes much stronger for bad news, and the relative importance of these two components depends on the nature of the news it conveys.

\section{Additional Analyses}

\subsection{The Alternative Estimations of Cash-flow News and Discount-rate News}

Although the VAR approach is currently the state-of-the-art practice in implementing the return decomposition and is widely used in many disciplines (see Chen and Zhao, 2009), it is not free from controversy. For example, the conclusions drawn from the VAR approach may be sensitive to the sample period (Chen, 2009), the choice of state variables, and the way in which cash-flow news is measured (i.e., whether cash-flow news is directly modeled or backed out as the residual) (Chen and Zhao, 2009). To address such concerns, we perform a comprehensive set of additional tests as described below.

First, we use the weighted least squares (WLS) instead of the OLS to check the robustness to the estimation method. We deflate the data for each firm-year by the number of 
firms in the corresponding cross-section to weigh each cross-section equally (Vuolteenaho, 2002).

Second, to address the concern whether the VAR parameters are constant across firms within the same industry, we estimate the VAR system separately for each Fama-French (1997) industry as suggested by Callen and Segal (2010). This approach yields the VAR parameters at the industry level, but the news variables can be computed at the firm-year level.

Third, to address the concern that cash-flow news, when measured as the residual, inherits the large misspecification error, we use two approaches: (1) estimating cash-flow news directly $\left(N c f_{t}=\mathrm{e}_{2}{ }^{\prime}(\mathrm{I}-\rho \Gamma)^{-1} \eta_{\mathrm{t}}\right)$ and discount-rate news residually as the difference between the unexpected return and cash-flow news, and (2) estimating both cash-flow news and discount-rate news directly and define the residual news ( $N$ residual $))$ as the third component of unexpected returns.

Fourth, we partition the full sample period into two periods (1986-1998 and 19992008) and estimate the VAR system separately for them to check whether the results are sensitive to the estimation period.

Finally, we employ an alternative method to decompose unexpected returns as proposed by Chen et al. (2013) that does not rely on the predictive regression of the VAR model. Following Chen et al. (2013), we estimate the implied cost of equity capital (ICC) using earnings forecasts from IBES as a measure of cash-flow expectation for each firm and at each point in time (Pastor et al., 2008). A price change between year $t$ and year $t+\mathrm{j}$ is decomposed into two parts: (1) cash-flow news defined as the price change holding ICC constant, and (2) discount-rate news defined as the price change holding cash flows constant (see Chen et al., (2013) for a detail). The use of this alternative method, which does not rely on the VAR model, enhances confidence in our results, although this alternative method is 
silent about how an expected-return component can be extracted from the price change. ${ }^{16}$

In untabulated results, we find that all the results from these tests are similar to those reported previously. In sum, we conclude that the results are not sensitive to the specific method to measure cash-flow news and discount-rate news.

\subsection{Causality between the Credit Rating Changes and News Variables}

We document that credit rating changes are more strongly associated with cash-flow news than with discount-rate news. We note that, however, this contemporaneous relation may reflect the stock market's reactions to rating changes because our news variables are estimated from stock returns, raising a concern of reverse causality. To address this concern, we test a lead-lag relation between rating changes and news variables. First, we use lagged news variables as the independent variables to rule out the possibility that stock returns respond to rating changes. The results presented in Column (1) of Table 8 are similar to those previously reported, leaving our inference unaffected. Second, we use lagged credit rating changes as the dependent variable as a falsification test; under our assumption that the empirical relation reflects rating agency's incorporation of news, there should be no relation between lagged rating changes and current news variables. Column (2) of Table 8 presents the results. Consistent with our prediction, we find an insignificant coefficient on $N c f_{t}$, inconsistent with the cash-flow news variable reflecting rating change events. In addition, we find a positive and significant coefficient on $N r_{t}$, which is in contrast to the predicted negative association. Overall, it is unlikely that our main finding merely reflects the market's reaction to rating changes.

\subsection{Shareholder-bondholder Conflicts}

As cash-flow news and discount-rate news are measured using stock returns, and

\footnotetext{
16 That is, Chen et al. (2013) decompose the realized return (excluding dividends) into cash-flow news and discount-rate news. However, conceptually, the realized return should also include the expected return component. 
credit ratings represent the bondholders' perspective, our main results can be subject to measurement errors or biases arising from potential shareholder-bondholder conflicts. However, we believe that this is not a serious concern for several reasons. ${ }^{17}$ First, many papers argue that stockholder-bondholder conflicts are typically small (Fama and Miller, 1972; Andrade and Kaplan, 1998; Parrino and Weisbach, 1999). Second, there is abundant empirical evidence that rating changes are associated with changes in stock prices (Holthausen and Leftwich, 1986; Hand et al., 1992; Dichev and Piotroski, 2001; Beaver et al., 2006). Finally, several studies find that stock returns can predict firm bankruptcy, which credit ratings aim to assess (Watt and Zimmerman, 1986, p.116; Shumway, 2001).

Nevertheless, to check the robustness, we examine whether the results are conditional on the magnitude of shareholder-bondholder conflicts. We use three proxies for shareholder-bondholder conflicts: leverage, stock return volatility, and whether the credit rating is investment grade or not (Ahmed et al., 2002). We expect that firms with high leverage, high return volatility, and non-investment-grade ratings likely experience greater shareholder-bondholder conflicts. If our finding of a greater role of cash-flow news is observed only for the subsample with a high level of shareholder-bondholder conflicts, it is likely that our results may be driven by measurement errors or biases. The untabulated results, however, show that the difference between the two coefficients $\left(N c f_{t}\right.$ and $\left.N r_{t}\right)$ is more pronounced for the subsample with a low level of shareholder-bondholder conflicts (low leverage and low stock return volatility), or the difference is statistically insignificant (investment-grade and non-investment-grade ratings). Therefore, the measurement errors due to potential conflicts between shareholders and bondholders, if any, do not seem to create a bias against the findings.

\subsection{Rating Agencies' Inefficient Information Processes and Conflicts of Interest}

17 See Beaver et al. (2006) for a similar argument. 
There are growing concerns that credit rating agencies lack independence due to the issuers-pay-fees structure. Recently, some have additionally questioned credit rating agencies' competence in assessing credit risk, particularly with respect to rating mortgage-backed and structured finance deals (Beales and Davies, 2007). Thus, credit ratings may not reflect the probability of default in an unbiased and timely manner due to rating agencies' own incentives and/or inefficient information processes. To check whether these concerns affect the main conclusion, we partition the sample by the proxies for information uncertainty (firm age, analyst coverage, and firm size) and rating agencies' conflicts of interest (the amount of debt issuance) and then examine whether the results hold for partitioned groups. ${ }^{18}$ The untabulated results show that cash-flow news is more strongly associated with credit rating changes than discount-rate news for all subsamples.

\subsection{The Upgrades versus Downgrades}

The effect of cash-flow news and discount-rate news might be different for rating upgrades and for downgrades. To examine this possibility, we divide the sample into subsamples of rating upgrades $\left(\triangle R A T I N G_{t}>0\right)$ and rating downgrades $\left(\triangle R A T I N G_{t}<0\right)$, and estimate the ordered logit for each group. A caveat with this analysis is that the partitioning of the sample based on the dependent variable $\left(\triangle R A T I N G_{t}\right)$ would reduce the power of the test and bias the coefficient toward zero. That is, this subsample analysis would be limited to the effect within upgrade groups or within downgrade groups (i.e., whether cash-flow news affects the number of notches for rating upgrades). Untabulated results show that neither $N c f_{t}$ nor $N r_{t}$ is significant for the subsample with rating upgrades. This loss of significance seems to be due to the reduced power as discussed previously. However, both $N c f_{t}$ and $N r_{t}$ are

\footnotetext{
18 The underlying reasoning behind the use of the amount of debt issuance for a proxy for conflicts of interest is conceptually similar to the argument that audit fee dependence impairs auditor independence (Craswell et al., 2003). We follow Bradshaw et al. (2006) in defining the amount of debt issuance as the net cash received from the issuance (and/or reduction) of debt. The use of cash received from the issuance (not the reduction) of debt does not change the results. 
significant for the subsample with rating downgrades even in the presence of reduced power. For this subsample, the magnitude of the coefficient on $N c f_{t}$ is greater than that on $N r_{t}$, consistent with the main findings.

\subsection{The Use of Quarterly Data}

While we follow prior studies (e.g., Vuolteenaho, 2002) and use annual data to measure credit rating changes and news variables, we also use quarterly data here to better reflect the nature of rating changes as an event. To make sure that rating changes reflect news (instead of stock returns reacting to rating changes), we measure stock returns over the quarter and measure rating changes as the difference between ratings at the end of current quarter and those at the end of following quarter. We find that the results using the quarterly data are similar (untabulated). For example, the coefficient on cash-flow news $(0.318)$ is positive and significant, and the coefficient on discount-rate news $(-0.146)$ is negative and significant. Thus, our findings are robust to an alternative data interval to measure rating changes and news variables.

\subsection{Other Additional Analyses}

We perform several untabulated sensitivity tests. First, we use standard errors clustered by both firm and year (Gow et al., 2010). Second, we use different horizons to measure credit rating changes or stock returns. We define the credit rating change using credit ratings as of four or six months after the fiscal year-end and repeat all the analyses. We also use different stock return cumulation periods, such as starting four or six months after the beginning of the current fiscal year. Third, we conduct a sub-period analysis by dividing the sample period into two or three periods. Results from all of these untabulated tests do not change the tenor of the reported results.

\section{Conclusions}


Despite the prominent role of credit ratings in the capital market, relatively little is known about the rating decision process. This paper studies the relative importance of cashflow news and discount-rate news in credit rating decision. The findings suggest that rating changes are, on average, more strongly associated with cash-flow news than with discountrate news. When the news contains negative information about the firm, the relation becomes much stronger. Therefore, the relative importance of the two components of news should be evaluated with a consideration of the nature of the news.

Notwithstanding these important findings, this study is subject to several caveats. There is no consensus about which is the best method to implement the return decomposition. Cash-flow news and discount-rate news are extracted from stock returns; therefore, these variables may contain measurement errors. Our study focuses on the contemporaneous association, rather than the causal relation. In addition, this paper does not examine whether rating agencies fully reflect the information into their ratings (Sloan, 1996). Future research can explore whether rating agencies misprice (i.e., underestimate or overestimate) specific components of new information. 


\section{References}

Abhyankar, A., and A. Gonzalez, 2009, News and the cross-section of expected corporate bond returns, Journal of Banking \& Finance 33, pp. 996-1004.

Ahmed, A. S., B. K. Billings, R. M. Morton, and M. Stanford-Harris, 2002, The role of accounting conservatism in mitigating bondholder-shareholder conflicts over dividend policy and in reducing debt costs, The Accounting Review 77, pp. 867-890.

Andrade, G., and S. N. Kaplan, 1998, How costly is financial (not economic) distress? Evidence from highly leveraged transactions that became distressed, Journal of Finance 53, pp. 1443-1493.

Ashbaugh-Skaife, H., D. W. Collins, and R. LaFond, 2006, The effects of corporate governance on firms' credit ratings, Journal of Accounting and Economics 42, pp. $203-$ 243.

Ayers, B. C., S. K. Laplante, and S. T. McGuire, 2010, Credit ratings and taxes: The effect of book-tax differences on ratings changes, Contemporary Accounting Research 27, pp. $359-402$.

Beales, R. , and P. J. Davies, 2007, Rating agencies: The weak link? Financial Times, (May 17).

Beaver, W. H., C. Shakespeare, and M. T. Soliman, 2006, Differential properties in the ratings of certified versus non-certified bond-rating agencies, Journal of Accounting and Economics 42, pp. 303-334.

Beaver, W., M. McNichols, and R. Price, 2007, Delisting returns and their effect on accounting-based market anomalies, Journal of Accounting and Economics 43, pp. 341368 .

Blume, M. E., F. Lim, and A. C. MacKinlay, 1998, The declining credit quality of U.S. Corporate debt: Myth or reality? Journal of Finance 53, pp. 1389-1413.

Boot, A. W. A., T. T. Milbourn, and A. Schmeits, 2006, Credit ratings as coordination mechanisms, Review of Financial Studies 19, pp. 81-118.

Botosan, C. A., M. A. Plumlee, and H. Wen, 2011, The relation between expected returns, realized returns, and firm risk characteristics, Contemporary Accounting Research 28, pp. $1085-1122$.

Bradshaw, M. T., S. A. Richardson, and R. G. Sloan, 2006, The relation between corporate financing activities, analysts' forecasts and stock returns, Journal of Accounting and Economics 42, pp. 53-85.

Campbell, J. Y. , and R. J. Shiller, 1988, The dividend-price ratio and expectations of future dividends and discount factors, Review of Financial Studies 1, pp. 195-228. 
Campbell, J. Y., 1991, A variance decomposition for stock returns, Economic Journal 101, pp. 157-179.

Campbell, J. Y., and J. Ammer, 1993, What moves the stock and bond market? A variance decomposition for long-term asset returns, Journal of Finance 48, pp. 3-37.

Campbell, J. Y., and T. Vuolteenaho, 2004, Bad beta, good beta, American Economic Review 94, pp. 1249-1275.

Campbell, J. Y., C. Polk, and T. Vuolteenaho, 2010, Growth or glamour? Fundamentals and systematic risk in stock returns, Review of Financial Studies 23, pp. 305-344.

Callen, J. L., and D. Segal, 2004, Do accruals drive firm-level stock returns? A variance decomposition analysis, Journal of Accounting Research 42, pp. 527-560.

Callen, J. L., O.-K. Hope, and D. Segal, 2005, Domestic and foreign earnings, stock return variability, and the impact of investor sophistication, Journal of Accounting Research 43, pp. 377-412.

Callen, J. L., J. Livnat, and D. Segal, 2009, The impact of earnings on the pricing of credit default swaps, The Accounting Review 84, pp. 1363-1394.

Callen, J. L., and D. Segal, 2010, A variance decomposition primer for accounting research, Journal of Accounting, Auditing \& Finance 25, pp. 121-142.

Callen, J. L., D. Segal, and O.-K. Hope, 2010, The pricing of conservative accounting and the measurement of conservatism at the firm-year level, Review of Accounting Studies 15, pp. $145-178$.

Cantor, R., and C. Mann, 2003, Measuring the performance of corporate bond ratings, Moody's Special Comment, Moody's Investors Service.

Chandra, U., and N. Nayar, 1998, The information content of commercial paper rating downgrades: Further evidence, Journal of Accounting, Auditing \& Finance 13, pp. 417435 .

Chava, S., and A. Purnanandam, 2010, CEOs versus CFOs: Incentives and corporate policies, Journal of Financial Economics 97, pp. 263-278.

Chen, L., 2009, On the reversal of return and dividend growth predictibility: A tale of two periods, Journal of Financial Economics 92, pp. 128-151.

Chen, L., and X. Zhao, 2009, Return decomposition, Review of Financial Studies 22, pp. 5213-5249.

Chen, L., Z. Da, and X. Zhao, 2013, What drives stock price movement? Review of Financial Studies 26, pp. 841-876.

Cheng, M., and K. R. Subramanyam, 2008, Analyst following and credit ratings, 
Contemporary Accounting Research 25, pp. 1007-1043.

Cifuentes, A., 2008, Turmoil in U.S. credit markets: The role of the credit rating agencies, Testimony at the hearings by the Senate Committee on Banking, Housing and Urban Affairs, U.S. Senate, Washington, D. C.

Cohen, R. B., P. A. Gompers, and T. Vuolteenaho, 2002, Who underreacts to cash-flow news? Evidence from trading between individuals and institutions, Journal of Financial Economics 66, pp. 409-462.

Craswell, A., D. J. Stokes, and J. Laughton, 2003, Auditor independence and fee dependence, Journal of Accounting and Economics 33, pp. 253-275.

Dechow, P. M., 1994, Accounting earnings and cash flows as measures of firm performance: The role of accounting accruals, Journal of Accounting and Economics 18, pp. 3-42.

Defond, M. L., and J. Zhang, 2011, The timeliness of the bond market reaction to bad earnings news, Contermpoary Accounting Research 31, pp. 911-936.

Dichev, I. D., and J. D. Piotroski, 2001, The long-run stock returns following bond ratings changes, Journal of Finance 56, pp. 173-203.

Easton, P. D., S. J. Monahan, and F. P. Vasvari, 2009, Initial evidence on the role of accounting earnings in the bond market, Journal of Accounting Research 47, pp. 721-766.

Ederington, L. H., and J. C. Goh, 1998, Bond rating agencies and stock analysts: Who knows what when? Journal of Financial and Quantitative Analysis 33, pp. 569-585.

Fama, E., and M. Miller, 1972, The theory of finance, New York, Holt, Rinehart \& Winston.

Fama, E. F., and K. R. French, 1997, Industry costs of equity, Journal of Financial Economics 43, pp. 153-193.

Freese, J., and J. S. Long, 2006, Regression models in categorical dependent variables using Stata, College station, Stata Press.

Gkougkousi, X., 2014, Aggregate earnings and corporate bond markets, Journal of Accounting Research 52, pp. 75-106.

Goh, J. C., and L. H. Ederington, 1993, Is a bond rating downgrade bad news, good news, or no news for stockholders? Journal of Finance 48, pp. 2001-2008.

Gow, I. D., G. Ormazabal, and D. J. Taylor, 2010, Correcting for cross-sectional and timeseries dependence in accounting research, The Accounting Review 85, pp. 483-512.

Hagle, T. M., and G. E. Mitchell, 1992, Goodness-of-fit measures for probit and logit, American Journal of Political Science 36, pp. 762-784.

Hand, J. R. M., R. W. Holthausen, and R. W. Leftwich, 1992, The effect of bond rating 
agency announcements on bond and stock prices, Journal of Finance 47, pp. 733-752.

Hirshleifer, D., K. Hou, and S. H. Teoh, 2009, Accruals, cash flows, and aggregate stock returns, Journal of Financial Economics 91, pp. 389-406.

Holthausen, R. W., and R. W. Leftwich, 1986, The effect of bond rating changes on common stock prices, Journal of Financial Economics 17, pp. 57-89.

Horrigan, J. O., 1966, The determination of long-term credit standing with financial ratios, Journal of Accounting Research 4, pp. 44-62.

Jiang, J., 2008, Beating earnings benchmarks and the cost of debt, The Accounting Review 83, pp. 377-416.

Jorion, P., Z. Liu, and C. Shi., 2005, Informational effects of regulation FD: Evidence from rating agencies, Journal of Financial Economics 76, pp. 309-330.

Jorion, P., C. Shi, and S. Zhang, 2009, Tightening credit standards: The role of accounting quality, Review of Accounting Studies 14, pp. 123-160.

Kaplan, R. S., and G. Urwitz, 1979, Statistical models of bond ratings: A methodological inquiry, Journal of Business 52, pp. 231-261.

Kliger, D., and O. Sarig, 2000, The information value of bond ratings, Journal of Finance 55, pp. 2879-2902.

Lee, Y.-J., 2008, The effects of employee stock options on credit ratings, The Accounting Review 83, pp. 1273-1314.

McFadden, D., 1973, Conditional logit analysis of qualitative choice behavior, Frontiers of Econometrics, New York: Academic Press.

McKelvey, R. D., and W. Zavoina, 1975, A statistical model for the analysis of ordinal level dependent variables, Journal of Mathematical Sociology 4, pp. 103-120.

Merton, R. C., 1974, On the pricing of corporate debt: The risk structure of interest rates, Journal of Finance 29, pp. 449-470.

Parrino, R., and M. S. Weisbach, 1999, Measuring investment distortions arising from stockholder-bondholder conflicts, Journal of Financial Economics 53, pp. 3-42.

Pástor, L., M. Sinha, and B. Swaminathan, 2008, Estimating the intertemporal risk-return tradeoff using the implied cost of capital, Journal of Finance 63, pp. 2859-2897.

Petersen, M. A., 2009, Estimating standard errors in finance panel data sets: Comparing approaches, Review of Financial Studies 22, pp. 435-480.

Rogers, W. H., 1993, Regression standard erros in clustered samples, Stata Technical Bullentin Reprints, STB-13-STB-18: 88-94. 
Sadka, G., 2007, Understanding stock price volatility: The role of earnings, Journal of Accounting Research 45, pp. 199-228.

Securities and Exchange Commission (SEC), 2003, Report on the role \& function of credit rating agencies in the operation of the securities markets, SEC: Washington, D. C.

Sengupta, P., 1998, Corporate disclosure quality and the cost of debt, The Accounting Review 73, pp. 459-474.

Shao, J., and J. N. K. Rao, 1993, Jackknife inference for heteroscedastic linear regression models, Canadian Journal of Statistics 21, pp. 377-395.

Shiller, R. J., and A. E. Beltratti, 1992, Stock prices and bond yields: Can their comovements be explained in terms of present value models? Journal of Monetary Economics 30, pp. $25-46$.

Shumway, T., 2001, Forecasting bankruptcy more accurately: A simple hazard model, Journal of Business 74, pp. 101-124.

Sloan, R. G., 1996, Do stock prices fully reflect information in accruals and cash flows about future earnings? The Accounting Review 71, pp. 289-315.

Standard \& Poor's (S\&P), 2006, Corporate ratings criteria 2006, New York: Standard \& Poor's.

Vuolteenaho, T., 2002, What drives firm-level stock returns? Journal of Finance 57, pp. 233264.

Watt, R., and J. Zimmerman, 1986, Positive Accounting Theory, Prentice Hall, Engelwood Cliffs, NJ. 


\section{Table 1 Sample selection and the distribution of credit ratings}

Panel A shows the sample selection procedure in detail. In Panel B, $R A T I N G_{t}$ is S\&P's long-term issuer-level credit ratings (SPLTICRM) as of three months after the fiscal year ends, converted to numerical values between $1\left(\mathrm{CCC}+\right.$ or below) and 17 (AAA). A higher value of $R A T I N G_{t}$ indicates better credit quality. In Panel C, $\triangle R A T I N G_{t}=R A T I N G_{t}-R A T I N G_{t-1}$. The sample is the 11,354 firm-year observations for the period 1986-2008.

Panel A. Sample selection

\begin{tabular}{lr}
\hline All firm-year observations with December fiscal year ends on COMPUSTAT for 1986-2008 & 89,772 \\
(excluding financial and utilities sector) & $(22,549)$ \\
Less observations with missing market value of equity for year $t$ and $t-1$ & $(8,135)$ \\
Less observations with missing or negative book value of equity for year $t$ and $t-1$ & $(9,753)$ \\
Less observations with missing stock returns and return on equity for year $t$ and $t-1$ & $(3,849)$ \\
Less observations with lagged market value less than \$10 million & 45,486 \\
Firm-year observations to estimate the VAR model & $(33,648)$ \\
Less observations without S\&P long-term issuer-level credit ratings (current and lagged) & 11,838 \\
& $(484)$ \\
\hline & 11,354 \\
\hline
\end{tabular}

Panel B. The distribution of credit ratings

\begin{tabular}{|c|c|c|c|c|c|}
\hline $\mathrm{S} \& \mathrm{P}$ ratings & $R_{A T I N G}$ & Frequency & Percentage $(\%)$ & $\begin{array}{c}\text { Cumulative } \\
\text { percentage }(\%)\end{array}$ & $\begin{array}{c}\text { Investment/ } \\
\text { Non-investment }\end{array}$ \\
\hline AAA & 17 & 203 & 1.79 & 1.79 & \multirow{10}{*}{$\begin{array}{c}\text { Investment } \\
\text { grade } \\
(60.2 \%)\end{array}$} \\
\hline $\mathrm{AA}+$ & 16 & 75 & 0.66 & 2.45 & \\
\hline $\mathrm{AA}$ & 15 & 364 & 3.21 & 5.66 & \\
\hline AA- & 14 & 330 & 2.91 & 8.57 & \\
\hline $\mathrm{A}+$ & 13 & 559 & 4.92 & 13.49 & \\
\hline A & 12 & 1,060 & 9.34 & 22.83 & \\
\hline A- & 11 & 890 & 7.84 & 30.67 & \\
\hline $\mathrm{BBB}+$ & 10 & 1,047 & 9.22 & 39.89 & \\
\hline BBB & 9 & 1,305 & 11.49 & 51.38 & \\
\hline BBB- & 8 & 1,001 & 8.82 & 60.20 & \\
\hline $\mathrm{BB}+$ & 7 & 709 & 6.24 & 66.44 & \multirow{7}{*}{$\begin{array}{c}\text { Non-investment } \\
\text { grade } \\
(39.8 \%)\end{array}$} \\
\hline BB & 6 & 925 & 8.15 & 74.59 & \\
\hline BB- & 5 & 1,116 & 9.83 & 84.42 & \\
\hline $\mathrm{B}+$ & 4 & 1,005 & 8.85 & 93.27 & \\
\hline B & 3 & 419 & 3.69 & 96.96 & \\
\hline B- & 2 & 211 & 1.86 & 98.82 & \\
\hline $\mathrm{CCC}+$ or below & 1 & 135 & 1.18 & 100.00 & \\
\hline Total & & 11,354 & 100.00 & & \\
\hline
\end{tabular}


Panel C. The distribution of credit rating changes

\begin{tabular}{|c|c|c|c|c|c|}
\hline $\begin{array}{c}\text { Credit Rating } \\
\text { Changes }\end{array}$ & $\triangle R A T I N G_{t}$ & Frequency & Percent & & $\begin{array}{c}\text { Cumulative } \\
\text { Percentage }(\%)\end{array}$ \\
\hline \multirow{4}{*}{ Upgrade } & 4 & 12 & 0.11 & \multirow{4}{*}{10.11} & 0.11 \\
\hline & 3 & 30 & 0.26 & & 0.37 \\
\hline & 2 & 194 & 1.71 & & 2.08 \\
\hline & 1 & 912 & 8.03 & & 10.11 \\
\hline No Change & 0 & 8,692 & 76.55 & 76.55 & 86.66 \\
\hline \multirow{4}{*}{ Downgrade } & -1 & 978 & 8.61 & \multirow{4}{*}{13.34} & 95.27 \\
\hline & -2 & 369 & 3.25 & & 98.52 \\
\hline & -3 & 128 & 1.13 & & 99.65 \\
\hline & -4 & 39 & 0.35 & & 100.00 \\
\hline Total & & 11,354 & 100.00 & & \\
\hline
\end{tabular}




\section{Table 2 Descriptive statistics}

Panel A of this table reports descriptive statistics for the sample of 11,354 firm-year observations for the period

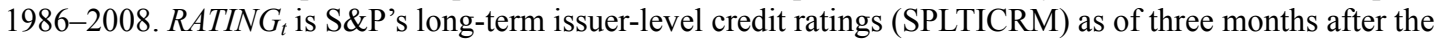
fiscal year ends, converted to numerical values between 1 (CCC+ or below) and 17 (AAA) according to Panel B of Table 1. $\Delta R A T I N G_{t}=R A T I N G_{t}-$ RATING $_{t-1} . N c f_{t}$ and $N r_{t}$ are cash-flow news and discount-rate news computed from Equations (6) and (7), respectively. $C N c f_{t}$ is current-period cash-flow news estimated as the residual of Equation (4b), $\eta_{2 t} . F N c f_{t}$ is future-period cash-flow news, defined as $N c f_{t}-C N c f_{t}$. SIZE $E_{t}$ is the log of market value of equity (CSHO*PRCC_F). INTCOV $V_{t}$ is the $\log$ of one plus interest coverage ratio. Interest coverage ratio is defined as operating income before depreciation (OIBDP) divided by interest expense (XINT). $R O A_{t}$ is return on assets, defined as income before extraordinary items (IB) divided by average total assets (AT). $L E V_{t}$ is the ratio of total debt (DLTT+DLC) to total assets (AT). CAP_INTEN is $_{t}$ gross property, plant and equipment (PPEGT) divided by total assets. $A G R W_{t}$ is the total asset growth defined as (Total assets $\mathrm{t}_{\mathrm{t}}-$ Total assets $\left._{\mathrm{t}-1}\right) /$ Total $_{\text {assets }} \mathrm{t}_{-1}$. STDRET $T_{t}$ is the standard deviation of daily stock returns during the fiscal year. Change variables $(\Delta)$ are defined as the first difference of the above variables, such as $\triangle S I Z E_{t}=S I Z E_{t}-S I Z E_{t-1}$. Panel B shows the descriptive statistics for the subsample with rating downgrades and those with rating upgrades. The sample is 1,514 observations with rating downgrades and 1,148 observations with rating upgrades.

\section{Panel A. Full sample}

\begin{tabular}{lrrrrr}
\hline & Mean & Std & Q1 & Median & Q3 \\
\hline RATING $_{t}$ & 8.513 & 3.606 & 5.000 & 9.000 & 11.000 \\
$\Delta R A T I N G_{t}$ & -0.072 & 0.746 & 0.000 & 0.000 & 0.000 \\
$N c f_{t}$ & 0.060 & 0.354 & -0.108 & 0.082 & 0.270 \\
$N r_{t}$ & -0.004 & 0.112 & -0.060 & 0.000 & 0.060 \\
$C N c f_{t}$ & 0.077 & 0.192 & 0.023 & 0.089 & 0.160 \\
$F N c f_{t}$ & -0.015 & 0.309 & -0.180 & -0.005 & 0.161 \\
$\Delta S I Z E_{t}$ & 0.088 & 0.197 & -0.012 & 0.057 & 0.147 \\
$\triangle I N T C O V_{t}$ & 0.007 & 0.416 & -0.165 & 0.030 & 0.203 \\
$\triangle R O A_{t}$ & -0.003 & 0.054 & -0.021 & 0.000 & 0.018 \\
$\Delta L E V_{t}$ & 0.000 & 0.069 & -0.035 & -0.005 & 0.030 \\
$\triangle C A P I N T_{t}$ & 0.003 & 0.087 & -0.026 & 0.008 & 0.039 \\
$\triangle A G R W_{t}$ & -0.052 & 0.423 & -0.128 & -0.008 & 0.092 \\
$\Delta S T D R E T_{t}$ & 0.001 & 0.009 & -0.004 & 0.000 & 0.004 \\
\hline
\end{tabular}

Panel B. Subsample with rating changes

\begin{tabular}{lrrrr}
\hline & \multicolumn{2}{c}{ Downgrades } & \multicolumn{2}{c}{ Upgrades } \\
\hline RATING $_{t}$ & Mean & Median & Mean & Median \\
$\Delta R A T I N G_{t}$ & 7.209 & 7.000 & 8.113 & 8.000 \\
$N c f_{t}$ & -1.490 & -1.000 & 1.253 & 1.000 \\
$N r_{t}$ & -0.121 & -0.047 & 0.169 & 0.156 \\
$C N c f_{t}$ & 0.009 & 0.017 & -0.003 & -0.005 \\
$F N c f_{t}$ & -0.008 & 0.055 & 0.108 & 0.103 \\
$\Delta S I Z E_{t}$ & -0.106 & -0.073 & 0.057 & 0.050 \\
$\Delta I N T C O V_{t}$ & 0.049 & 0.014 & 0.149 & 0.105 \\
$\triangle R O A_{t}$ & -0.195 & -0.136 & 0.170 & 0.159 \\
$\Delta L E V_{t}$ & -0.027 & -0.016 & 0.011 & 0.008 \\
$\Delta C A P I N T_{t}$ & 0.030 & 0.019 & -0.026 & -0.023 \\
$\triangle A G R W_{t}$ & 0.009 & 0.013 & -0.008 & 0.002 \\
$\Delta S T D R E T_{t}$ & -0.059 & -0.031 & 0.012 & 0.020 \\
\hline
\end{tabular}




\section{Table 3 Correlation}

This table presents the Pearson correlation coefficients. The sample is 11,354 firm-year observations for the period 1986-2008. $P$-values are reported in the parentheses. See Table 2 for the variable definitions.

\begin{tabular}{|c|c|c|c|c|c|c|c|c|c|c|c|}
\hline & $N c f_{t}$ & $N r_{t}$ & $C N c f_{t}$ & $F N c f_{t}$ & $\triangle S I Z E_{t}$ & $\triangle I N T C O V_{t}$ & $\Delta R O A_{t}$ & $\Delta L E V_{t}$ & $\triangle C A P I N T_{t}$ & $\triangle A G R W_{t}$ & $\triangle S T D R E T_{t}$ \\
\hline \multirow[t]{2}{*}{$\triangle R A T I N G_{t}$} & 0.23 & -0.04 & 0.18 & 0.15 & 0.13 & 0.22 & 0.19 & -0.20 & -0.05 & 0.05 & -0.17 \\
\hline & $(<.0001)$ & $(<.0001)$ & $(<.0001)$ & $(<.0001)$ & $(<.0001)$ & $(<.0001)$ & $(<.0001)$ & $(<.0001)$ & $(<.0001)$ & $(<.0001)$ & $(<.0001)$ \\
\hline \multirow[t]{2}{*}{$N c f_{t}$} & 1.00 & -0.18 & 0.49 & 0.82 & 0.15 & 0.22 & 0.33 & -0.26 & -0.15 & 0.14 & -0.16 \\
\hline & & $(<.0001)$ & $(<.0001)$ & $(<.0001)$ & $(<.0001)$ & $(<.0001)$ & $(<.0001)$ & $(<.0001)$ & $(<.0001)$ & $(<.0001)$ & $(<.0001)$ \\
\hline \multirow[t]{2}{*}{$N r_{t}$} & & 1.00 & 0.21 & -0.35 & 0.14 & -0.03 & 0.10 & -0.13 & -0.05 & 0.01 & 0.02 \\
\hline & & & $(<.0001)$ & $(<.0001)$ & $(<.0001)$ & $(<.0001)$ & $(<.0001)$ & $(<.0001)$ & $(<.0001)$ & $(0.12)$ & $(0.04)$ \\
\hline \multirow[t]{2}{*}{$C N c f_{t}$} & & & 1.00 & -0.08 & 0.13 & 0.24 & 0.59 & -0.24 & -0.15 & 0.13 & -0.11 \\
\hline & & & & $(<.0001)$ & $(<.0001)$ & $(<.0001)$ & $(<.0001)$ & $(<.0001)$ & $(<.0001)$ & $(<.0001)$ & $(<.0001)$ \\
\hline \multirow[t]{2}{*}{$F N c f_{t}$} & & & & 1.00 & 0.10 & 0.09 & 0.01 & -0.13 & -0.07 & 0.07 & -0.11 \\
\hline & & & & & $(<.0001)$ & $(<.0001)$ & $(0.50)$ & $(<.0001)$ & $(<.0001)$ & $(<.0001)$ & $(<.0001)$ \\
\hline \multirow[t]{2}{*}{$\overline{\Delta S I Z E_{t}}$} & & & & & 1.00 & -0.06 & 0.05 & 0.20 & -0.45 & 0.46 & -0.06 \\
\hline & & & & & & $(<.0001)$ & $(<.0001)$ & $(<.0001)$ & $(<.0001)$ & $(<.0001)$ & $(<.0001)$ \\
\hline \multirow[t]{2}{*}{$\triangle I N T C O V_{t}$} & & & & & & 1.00 & 0.48 & -0.39 & -0.02 & 0.08 & -0.11 \\
\hline & & & & & & & $(<.0001)$ & $(<.0001)$ & $(0.04)$ & $(<.0001)$ & $(<.0001)$ \\
\hline \multirow[t]{2}{*}{$\Delta R O A_{t}$} & & & & & & & 1.00 & -0.33 & -0.13 & 0.12 & -0.17 \\
\hline & & & & & & & & $(<.0001)$ & $(<.0001)$ & $(<.0001)$ & $(<.0001)$ \\
\hline \multirow[t]{2}{*}{$\Delta L E V_{t}$} & & & & & & & & 1.00 & -0.05 & 0.14 & 0.14 \\
\hline & & & & & & & & & $(<.0001)$ & $(<.0001)$ & $(<.0001)$ \\
\hline \multirow[t]{2}{*}{$\triangle C A P_{-} I N T_{t}$} & & & & & & & & & 1.00 & -0.32 & 0.08 \\
\hline & & & & & & & & & & $(<.0001)$ & $(<.0001)$ \\
\hline \multirow[t]{2}{*}{$\triangle A G R W_{t}$} & & & & & & & & & & 1.00 & -0.10 \\
\hline & & & & & & & & & & & $(<.0001)$ \\
\hline
\end{tabular}




\section{Table 4 Estimated parameters of the VAR model}

This table reports the parameter estimates for the VAR model in Equation (4). The parameters in the table correspond to the following system:

$$
z_{t}=\Gamma z_{t-1}+\eta_{t}, \Sigma=E\left(\eta_{t}, \eta_{t}{ }^{\prime}\right)
$$

The state variables in $z_{\mathrm{t}}$ include the mean-adjusted cum dividend annual excess return $\left(r_{t}\right)$, the mean-adjusted return on equity $\left(\right.$ roe $\left._{t}\right)$, and the mean-adjusted book-to-market ratio $\left(b m_{t}\right) . r_{t}$ is the log of one plus the annual cum dividend return minus the log of one plus the annualized three-month Treasury bill rate. The 12-month return cumulation period starts three months after the beginning of the current fiscal year. roe $_{t}$ is the log of one plus ROE minus the log of one plus the annualized three-month Treasury bill rate. ROE is computed as income before extraordinary items (IB), divided by beginning of period book value of equity (CEQ). $b m_{t}$ is the log of the book-to-market ratio at year end. The book-to-market ratio is the book value of equity (CEQ) divided by the market value of equity (CSHO*PRCC_F). All variables in the VAR system are cross-sectionally demeaned. For each parameter, we report three numbers. The first number is the OLS estimate of the parameter. The second number (in parentheses) is a robust standard error computed using the Rogers' (1993) method. The third number (in brackets) is a robust jackknife standard error computed using a jackknife method outlined by Shao and Rao (1993). The top and bottom $1 \%$ of each of the state variables in the VAR model is winsorized every year to mitigate outliers. The sample for the VAR estimation is 45,486 firm-year observations for the period 1986-2008. See Panel A of Table 1 for the sample selection.

\begin{tabular}{|c|c|c|c|c|c|c|c|c|}
\hline & \multicolumn{3}{|c|}{$\Gamma$} & \multirow[b]{2}{*}{$\lambda_{1}^{\prime}$} & \multirow[b]{2}{*}{$\left(e_{1}+\lambda_{1}\right)^{\prime}$} & \multicolumn{3}{|c|}{$\Sigma$} \\
\hline & $r_{t-1}$ & roe $_{t-1}$ & $b m_{t-1}$ & & & $r_{t}$ & roe $_{t}$ & $b m_{t}$ \\
\hline \multirow[t]{3}{*}{$r_{t}$} & 0.044 & 0.045 & 0.074 & 0.025 & 1.025 & 0.262 & 0.060 & -0.150 \\
\hline & $(0.040)$ & $(0.033)$ & $(0.026)$ & & & $(0.035)$ & $(0.011)$ & $(0.024)$ \\
\hline & {$[0.044]$} & {$[0.034]$} & [0.028] & & & {$[0.035]$} & {$[0.011]$} & [0.024] \\
\hline \multirow[t]{3}{*}{$\mathrm{roe}_{t}$} & 0.179 & 0.331 & 0.003 & 0.119 & 0.119 & 0.060 & 0.113 & 0.009 \\
\hline & $(0.023)$ & $(0.035)$ & $(0.010)$ & & & $(0.011)$ & $(0.010)$ & $(0.007)$ \\
\hline & {$[0.025]$} & {$[0.036]$} & [0.011] & & & [0.011] & {$[0.010]$} & {$[0.007]$} \\
\hline \multirow[t]{3}{*}{$b m_{t}$} & -0.137 & 0.127 & 0.777 & 0.295 & 0.295 & -0.150 & 0.009 & 0.244 \\
\hline & $(0.026)$ & $(0.028)$ & $(0.019)$ & & & $(0.024)$ & $(0.007)$ & $(0.028)$ \\
\hline & {$[0.028]$} & {$[0.028]$} & {$[0.020]$} & & & {$[0.024]$} & {$[0.007]$} & [0.028] \\
\hline
\end{tabular}


A Return Decomposition Approach on Credit Rating Changes

Table 5 Regression of the change in credit ratings on cash-flow and discount-rate news

This table reports the ordered logit results of regressing changes in credit ratings $\left(\triangle R A T I N G_{t}\right)$ on cash-flow $\left(N c f_{t}\right)$ and discount-rate news $\left(N r_{t}\right)$. Column (3) reports ordered logit results after excluding observations with zero credit rating changes. Column (4) reports the OLS results. The dependent variable is $\triangle R A T I N G_{t}$, which is the change in S\&P's long-term issuer-level credit ratings as of three months after the fiscal year ends. The level of credit rating is converted to numerical values between 1 (CCC+ or below) and 17 (AAA) according to Panel B of Table 1. A positive (negative) value of $\triangle R A T I N G_{t}$ indicates upgrades (downgrades). See Table 2 for the definitions of other variables. All independent variables are standardized to have a zero mean and unit variance. We reports $p$-values based on standard errors clustered by firm in parentheses. The sample is 11,354 firm-year observations for the period 1986-2008. The symbols *, **, and *** denote significance at the $10 \%, 5 \%$, and $1 \%$ levels, respectively, in two-tailed tests.

\begin{tabular}{|c|c|c|c|c|}
\hline & \multicolumn{4}{|c|}{ Dependent Variable $=\Delta R A T I N G_{t}$} \\
\hline & & Ordered Lc & & OLS \\
\hline & (1) & (2) & $\begin{array}{l}\text { (3) After excluding } \\
\text { zero rating changes }\end{array}$ & (4) \\
\hline$N c f_{t}$ & $\begin{array}{l}0.244 * * * \\
(0.00)\end{array}$ & & $\begin{array}{l}0.313^{* * *} \\
(0.00)\end{array}$ & $\begin{array}{l}0.085^{* * *} \\
(0.00)\end{array}$ \\
\hline$C N c f_{t}$ & & $\begin{array}{l}0.217^{* * *} \\
(0.00)\end{array}$ & & \\
\hline$F N c f_{t}$ & & $\begin{array}{l}0.171^{* * *} \\
(0.00)\end{array}$ & & \\
\hline$N r_{t}$ & $\begin{array}{l}-0.123^{* * *} \\
(0.00)\end{array}$ & $\begin{array}{l}-0.151^{* * *} \\
(0.00)\end{array}$ & $\begin{array}{l}-0.163^{* * *} \\
(0.00)\end{array}$ & $\begin{array}{l}-0.034^{* * *} \\
(0.00)\end{array}$ \\
\hline$\triangle S I Z E_{t}$ & $\begin{array}{l}0.442^{* * * *} \\
(0.00)\end{array}$ & $\begin{array}{l}0.443 * * * \\
(0.00)\end{array}$ & $\begin{array}{l}0.603^{* * *} \\
(0.00)\end{array}$ & $\begin{array}{l}0.129^{* * *} \\
(0.00)\end{array}$ \\
\hline$\triangle I N T C O V_{t}$ & $\begin{array}{l}0.348^{* * *} \\
(0.00)\end{array}$ & $\begin{array}{l}0.355^{* * *} \\
(0.00)\end{array}$ & $\begin{array}{l}0.523^{* * *} \\
(0.00)\end{array}$ & $\begin{array}{l}0.097^{* * *} \\
(0.00)\end{array}$ \\
\hline$\triangle R O A_{t}$ & $\begin{array}{l}0.055^{*} \\
(0.07)\end{array}$ & $\begin{array}{r}0.003 \\
(0.94)\end{array}$ & $\begin{array}{r}0.078 \\
(0.16)\end{array}$ & $\begin{array}{l}0.026^{* *} \\
(0.01)\end{array}$ \\
\hline$\triangle L E V_{t}$ & $\begin{array}{l}-0.362^{* * *} \\
(0.00)\end{array}$ & $\begin{array}{l}-0.367 * * * \\
(0.00)\end{array}$ & $\begin{array}{l}-0.490 * * * \\
(0.00)\end{array}$ & $\begin{array}{l}-0.101 * * * \\
(0.00)\end{array}$ \\
\hline$\triangle C A P_{-} I N T E N_{t}$ & $\begin{array}{l}0.100^{* * *} \\
(0.00)\end{array}$ & $\begin{array}{l}0.101^{* * *} \\
(0.00)\end{array}$ & $\begin{array}{l}0.151^{* * *} \\
(0.00)\end{array}$ & $\begin{array}{l}0.030^{* * *} \\
(0.00)\end{array}$ \\
\hline$\triangle A G R W_{t}$ & $\begin{array}{l}-0.104 * * * \\
(0.00)\end{array}$ & $\begin{array}{l}-0.106^{* * *} \\
(0.00)\end{array}$ & $\begin{array}{l}-0.147 * * * \\
(0.00)\end{array}$ & $\begin{array}{l}-0.027 * * * \\
(0.00)\end{array}$ \\
\hline$\triangle S T D R E T_{t}$ & $\begin{array}{l}-0.337^{* * * *} \\
(0.00)\end{array}$ & $\begin{array}{l}-0.331 * * * \\
(0.00)\end{array}$ & $\begin{array}{l}-0.411 * * * \\
(0.00)\end{array}$ & $\begin{array}{l}-0.122 * * * \\
(0.00)\end{array}$ \\
\hline $\begin{array}{l}\text { Industry- and year-fixed } \\
\text { effects }\end{array}$ & Included & Included & Included & Included \\
\hline Test ( $p$-value) & & & & \\
\hline $\begin{array}{l}N c f_{t}=-N r_{t} \\
C N c f_{t}=F N c f_{t}\end{array}$ & $(0.01)^{* * *}$ & $(0.24)$ & $(0.05)^{* *}$ & $(0.01)^{* * *}$ \\
\hline $\begin{array}{l}C N c f_{t}=N r_{t} \\
F N c f_{t}=-N r_{t}\end{array}$ & & $\begin{array}{l}(0.11) \\
(0.67)\end{array}$ & & \\
\hline $\begin{array}{r}F N c f_{t}=-N r_{t} \\
\text { McFadden's } \mathrm{R}^{2}\end{array}$ & $8.11 \%$ & $8.14 \%$ & $14.92 \%$ & \\
\hline McKelvey \& Zavoina's $\mathrm{R}^{2}$ & $20.50 \%$ & $20.50 \%$ & $37.70 \%$ & \\
\hline OLS adj $R^{2}$ & & & & $14.54 \%$ \\
\hline $\mathrm{N}$ & 11,354 & 11,354 & 2,662 & 11,354 \\
\hline
\end{tabular}




\section{Table 6 Binary logit regression and marginal effects}

This table reports the binary logit results and marginal effects of independent variables. In Columns (1) through (3), the dependent variable is $U P G R A D E_{t}$, which is one if ratings are upgraded, and zero otherwise. In Columns (4) through (6), the dependent variable is $D O W N G R A D E_{t}$, which is one if ratings are downgraded, and zero otherwise. See Table 2 for the definitions of other variables. The marginal effects in Columns (2) and (5) show the effects of small change in independent variables on the probability of being upgraded or downgraded. The marginal effects are computed as $\mathrm{e}^{\beta^{\prime} \mathrm{x}} /\left(1+\mathrm{e}^{\beta^{\prime} \mathrm{x}}\right)$ where $\beta^{\prime} \mathrm{X}$ is evaluated at the mean values of $\mathrm{X}$. Columns (3) and (6) show changes in the probability of being upgraded or downgraded as a result of moving the variable of interest from the first to the third quartile, holding all other variables at their mean values. All independent variables are standardized to have a zero mean and unit variance. We reports $p$-values based on standard errors clustered by firm in parentheses. The sample is 11,354 firm-year observations for the period 1986-2008. The symbols $*, * *$, and $* * *$ denote significance at the $10 \%, 5 \%$, and $1 \%$ levels, respectively, in two-tailed tests.

\begin{tabular}{|c|c|c|c|c|c|c|}
\hline & \multicolumn{3}{|c|}{ Dependent variable $=U P G R A D E_{t}$} & \multicolumn{3}{|c|}{ Dependent variable $=D O W N G R A D E_{t}$} \\
\hline & $(1)$ & $(2)$ & (3) & $(4)$ & (5) & $(6)$ \\
\hline & $\begin{array}{c}\text { Logit } \\
\operatorname{Pr}(\text { Upgrade }=1)\end{array}$ & $\begin{array}{l}\text { Marginal } \\
\text { effect }\end{array}$ & $\begin{array}{l}\text { Change in } \\
\text { probability } \\
\text { (Q1vs.Q3) }\end{array}$ & $\begin{array}{c}\text { Logit } \\
\text { Pr(Downgrade }=1)\end{array}$ & $\begin{array}{l}\text { Marginal } \\
\text { effect }\end{array}$ & $\begin{array}{l}\text { Change in } \\
\text { probability } \\
\text { (Q1vs.Q3) }\end{array}$ \\
\hline$N c f_{t}$ & $\begin{array}{l}0.176^{* * *} \\
(0.00)\end{array}$ & 0.013 & $1.39 \%$ & $\begin{array}{l}-0.258 * * * \\
(0.00)\end{array}$ & -0.024 & $-2.51 \%$ \\
\hline$N r_{t}$ & $\begin{array}{l}-0.062 \\
(0.12)\end{array}$ & -0.005 & $-0.48 \%$ & $\begin{array}{l}0.148^{* * *} \\
(0.00)\end{array}$ & 0.014 & $1.46 \%$ \\
\hline$\triangle S I Z E_{t}$ & $\begin{array}{l}0.398^{* * *} \\
(0.00)\end{array}$ & 0.029 & $2.27 \%$ & $\begin{array}{l}-0.452^{* * *} \\
(0.00)\end{array}$ & -0.042 & $-3.47 \%$ \\
\hline$\triangle I N T C O V_{t}$ & $\begin{array}{l}0.335^{* * *} \\
(0.00)\end{array}$ & 0.025 & $2.19 \%$ & $\begin{array}{l}-0.343^{* * *} \\
(0.00)\end{array}$ & -0.032 & $-2.77 \%$ \\
\hline$\triangle R O A_{t}$ & $\begin{array}{l}-0.009 \\
(0.83)\end{array}$ & -0.001 & $-0.04 \%$ & $\begin{array}{l}-0.112 * * * \\
(0.00)\end{array}$ & -0.010 & $-0.74 \%$ \\
\hline$\triangle L E V_{t}$ & $\begin{array}{l}-0.382 * * * \\
(0.00)\end{array}$ & -0.028 & $-2.70 \%$ & $\begin{array}{l}0.308^{* * *} \\
(0.00)\end{array}$ & 0.028 & $2.67 \%$ \\
\hline$\triangle C A P_{-} I N T E N_{t}$ & $\begin{array}{r}0.061 \\
(0.15)\end{array}$ & 0.005 & $0.34 \%$ & $\begin{array}{l}-0.108^{* * * *} \\
(0.00)\end{array}$ & -0.010 & $-0.74 \%$ \\
\hline$\triangle A G R W_{t}$ & $\begin{array}{r}0.012 \\
(0.74)\end{array}$ & 0.001 & $0.05 \%$ & $\begin{array}{l}0.278^{* * *} \\
(0.00)\end{array}$ & 0.026 & $1.35 \%$ \\
\hline$\triangle S T D R E T_{t}$ & $\begin{array}{l}-0.176^{* * *} \\
(0.00)\end{array}$ & -0.013 & $-1.17 \%$ & $\begin{array}{l}0.401^{* * *} \\
(0.00)\end{array}$ & 0.037 & $3.23 \%$ \\
\hline $\begin{array}{l}\text { Industry-and year-fixed } \\
\text { effects }\end{array}$ & Included & & & Included & & \\
\hline $\begin{array}{l}\text { The probability of Upgrade } \\
=1 \text { (or Downgrade }=1 \text { ) at } \\
\text { the means of all variables }\end{array}$ & $7.96 \%$ & & & $10.23 \%$ & & \\
\hline $\begin{array}{l}\text { Test ( } p \text {-value }) \\
\qquad \mathrm{Ncf}_{\mathrm{t}}=-\mathrm{Nr}_{\mathrm{t}}\end{array}$ & $(0.08)^{*}$ & & & $(0.05)^{* *}$ & & \\
\hline McFadden's $\mathrm{R}^{2}$ & $8.78 \%$ & & & $13.09 \%$ & & \\
\hline McKelvey \& Zavoina's R ${ }^{2}$ & $18.20 \%$ & & & $22.00 \%$ & & \\
\hline $\mathrm{N}$ & 11,354 & & & 11,354 & & \\
\hline
\end{tabular}


Table 7 Regression of the change in credit ratings on cash-flow and discount-rate news: Good news versus bad news

This table reports the ordered logit results for the partitioned samples. The sample is partitioned according to the sign of the news (i.e., good versus bad) of cash-flow news $\left(N c f_{t}\right)$, and discount-rate news $\left(N r_{t}\right)$. The dependent variable is $\triangle R A T I N G_{t}$, which is the change in S\&P's long-term issuer-level credit ratings as of three months after the fiscal year ends. The level of credit rating is converted to numerical values between 1 (CCC + or below) and 17 (AAA) according to Panel $\mathrm{B}$ of Table 1 . A positive (negative) value of $\triangle R A T I N G_{t}$ indicates upgrades (downgrades). All independent variables are standardized to have a zero mean and unit variance for the sample analyzed. See Table 2 for the definitions of other variables. We reports $p$-values based on standard errors clustered by firm in parentheses. The full sample is 11,354 firm-year observations for the period 1986-2008. The symbols $* * *$, and $* * *$ denote significance at the $10 \%, 5 \%$, and $1 \%$ levels, respectively, in two-tailed tests.

\begin{tabular}{|c|c|c|c|c|}
\hline & \multicolumn{4}{|c|}{ Dependent variable $=\Delta R A T I N G_{t}$} \\
\hline & \multicolumn{4}{|c|}{ Ordered logit } \\
\hline & $N c f_{t}>0$ & $N c f_{t}<0$ & $N r_{t}<0$ & $N r_{l}>0$ \\
\hline & $(1)$ & $(2)$ & $(3)$ & $(4)$ \\
\hline & Good CF news & Bad CF news & Good DR news & Bad DR news \\
\hline \multirow[t]{2}{*}{$N c f_{t}$} & 0.028 & $0.331 * * *$ & $0.236^{* * *}$ & $0.237 * * *$ \\
\hline & $(0.44)$ & $(0.00)$ & $(0.00)$ & $(0.00)$ \\
\hline \multirow[t]{2}{*}{$N r_{t}$} & $-0.169 * * *$ & $-0.120 * * *$ & -0.032 & $-0.092 * *$ \\
\hline & $(0.00)$ & $(0.00)$ & $(0.40)$ & $(0.02)$ \\
\hline \multirow[t]{2}{*}{$\triangle S I Z E_{t}$} & $0.451 * * *$ & $0.426 * * *$ & $0.396 * * *$ & $0.460 * * *$ \\
\hline & $(0.00)$ & $(0.00)$ & $(0.00)$ & $(0.00)$ \\
\hline \multirow[t]{2}{*}{$\triangle I N T C O V_{t}$} & $0.331 * * *$ & $0.353 * * *$ & $0.299 * * *$ & $0.388 * * *$ \\
\hline & $(0.00)$ & $(0.00)$ & $(0.00)$ & $(0.00)$ \\
\hline \multirow[t]{2}{*}{$\triangle R O A_{t}$} & -0.011 & $0.141 * * *$ & $0.102 * *$ & 0.016 \\
\hline & $(0.77)$ & $(0.00)$ & $(0.02)$ & $(0.70)$ \\
\hline \multirow[t]{2}{*}{$\Delta L E V_{t}$} & $-0.491 * * *$ & $-0.186 * * *$ & $-0.385 * * *$ & $-0.330 * * *$ \\
\hline & $(0.00)$ & $(0.00)$ & $(0.00)$ & $(0.00)$ \\
\hline \multirow[t]{2}{*}{$\triangle C A P_{-} I_{N T E N}$} & $0.069 *$ & $0.156^{* * *}$ & $0.139 * * *$ & $0.067^{*}$ \\
\hline & $(0.08)$ & $(0.00)$ & $(0.00)$ & $(0.10)$ \\
\hline \multirow[t]{2}{*}{$\triangle A G R W_{t}$} & $-0.080 * *$ & $-0.135 * * *$ & $-0.154 * * *$ & $-0.067 * *$ \\
\hline & $(0.02)$ & $(0.00)$ & $(0.00)$ & $(0.05)$ \\
\hline \multirow[t]{2}{*}{$\triangle S T D R E T_{t}$} & $-0.269 * * *$ & $-0.358 * * *$ & $-0.289 * * *$ & $-0.389 * * *$ \\
\hline & $(0.00)$ & $(0.00)$ & $(0.00)$ & $(0.00)$ \\
\hline $\begin{array}{l}\text { Industry-and } \\
\text { year- fixed effects }\end{array}$ & Included & Included & Included & Included \\
\hline Test ( $p$-value) & $(0.01)^{* *}$ & $(0.00)^{* * *}$ & $(0.00)^{* * *}$ & $(0.02)^{* *}$ \\
\hline \multicolumn{5}{|l|}{$\mathrm{Ncf}_{\mathrm{t}}=-\mathrm{Nr}_{\mathrm{t}}$} \\
\hline McFadden's $\mathrm{R}^{2}$ & $6.45 \%$ & $8.90 \%$ & $8.09 \%$ & $8.61 \%$ \\
\hline $\begin{array}{l}\text { McKelvey \& } \\
\text { Zavoina's R }\end{array}$ & $16.60 \%$ & $22.00 \%$ & $20.10 \%$ & $21.80 \%$ \\
\hline $\mathrm{N}$ & 7,093 & 4,261 & 5,664 & 5,690 \\
\hline
\end{tabular}


A Return Decomposition Approach on Credit Rating Changes

\section{Table 8 The lead-lag relation between credit rating changes and news variables}

This table reports the results to examine the lead-lag relation between credit rating changes and news variables. Column (1) shows the ordered logit results of regressing changes in credit ratings $\left(\triangle R A T I N G_{t}\right)$ on lagged cashflow $\left(N c f_{t-1}\right)$ and discount-rate news $\left(N r_{t-1}\right)$. Column (2) reports the ordered logit results of regressing lagged changes in credit ratings $\left(\triangle R A T I N G_{t-1}\right)$ on current cash-flow $\left(N c f_{t}\right)$ and discount-rate news $\left(N r_{t}\right)$. $\triangle R A T I N G$ is the change in S\&P's long-term issuer-level credit ratings as of three months after the fiscal year ends. The level of credit rating is converted to numerical values between 1 (CCC+ or below) and 17 (AAA) according to Panel $\mathrm{B}$ of Table 1 . A positive (negative) value of $\triangle R A T I N G_{t}$ indicates upgrades (downgrades). See Table 2 for the definitions of other variables. All independent variables are standardized to have a zero mean and unit variance. We reports $p$-values based on standard errors clustered by firm in parentheses. The symbols *, **, and *** denote significance at the $10 \%, 5 \%$, and $1 \%$ levels, respectively, in two-tailed tests.

\begin{tabular}{|c|c|c|}
\hline & Dependent variable $=\Delta R A T I N G_{t}$ & Dependent variable $=\Delta R A T I N G_{t-1}$ \\
\hline & $(1)$ & $(2)$ \\
\hline \multirow[t]{2}{*}{$N c f_{t-1}$} & $0.443 * * *$ & \\
\hline & $(0.00)$ & \\
\hline \multirow[t]{2}{*}{$N r_{t-1}$} & $-0.055^{* *}$ & \\
\hline & $(0.04)$ & \\
\hline \multirow[t]{2}{*}{$N c f_{t}$} & & -0.013 \\
\hline & & $(0.66)$ \\
\hline \multirow[t]{2}{*}{$N r_{t}$} & & $0.092 * * *$ \\
\hline & & $(0.00)$ \\
\hline \multirow[t]{2}{*}{$\triangle S I Z E_{t}$} & $0.355^{* * *}$ & $0.503 * * *$ \\
\hline & $(0.00)$ & $(0.00)$ \\
\hline \multirow[t]{2}{*}{$\triangle I N T C O V_{t}$} & $0.302 * * *$ & $0.276 * * *$ \\
\hline & $(0.00)$ & $(0.00)$ \\
\hline \multirow[t]{2}{*}{$\triangle R O A_{t}$} & $0.117 * * *$ & $-0.284 * * *$ \\
\hline & $(0.00)$ & $(0.00)$ \\
\hline \multirow[t]{2}{*}{$\triangle L E V_{t}$} & $-0.352 * * *$ & -0.017 \\
\hline & $(0.00)$ & $(0.58)$ \\
\hline \multirow[t]{2}{*}{$\triangle C A P_{-} I N T E N_{t}$} & $0.114 * * *$ & $0.087 * *$ \\
\hline & $(0.00)$ & $(0.01)$ \\
\hline \multirow[t]{2}{*}{$\triangle A G R W_{t}$} & $-0.067 * *$ & $-0.217 * * *$ \\
\hline & $(0.02)$ & $(0.00)$ \\
\hline \multirow[t]{2}{*}{$\triangle S T D R E T_{t}$} & $-0.355^{* * *}$ & $-0.188 * * *$ \\
\hline & $(0.00)$ & $(0.00)$ \\
\hline Industry- and year-fixed effects & Included & Included \\
\hline \multicolumn{3}{|l|}{ Test ( $p$-value) } \\
\hline$N c f_{t-1}=-N r_{t-1}$ & $(0.00)^{* * *}$ & \\
\hline$N c f_{t}=-N r_{t}$ & & $(0.08)^{*}$ \\
\hline McFadden's $\mathrm{R}^{2}$ & $9.28 \%$ & $3.36 \%$ \\
\hline McKelvey \& Zavoina's R ${ }^{2}$ & $22.60 \%$ & $9.60 \%$ \\
\hline $\mathrm{N}$ & 10,432 & 10,080 \\
\hline
\end{tabular}

